\title{
Review \\ Enzyme Immobilization and Co-Immobilization: Main Framework, Advances and Some Applications
}

\author{
Joaquim Bié ${ }^{1}$, Bruno Sepodes ${ }^{1,2}\left(\mathbb{D}\right.$, Pedro C. B. Fernandes ${ }^{3,4,5, * \mathbb{C}}$ and Maria H. L. Ribeiro ${ }^{1,6} \mathbb{C}$
}

1 Research Institute for Medicines (i-Med.ULisboa), Faculty of Pharmacy, Universidade de Lisboa, Av. Prof. Gama Pinto, 1649-003 Lisboa, Portugal; joaqbie@yahoo.com.br (J.B.); bsepodes@ff.ulisboa.pt (B.S.); mhribeiro@ff.ul.pt (M.H.L.R.)

2 Department of Pharmacy, Pharmacology and Health Technologies, Faculty of Pharmacy, Universidade de Lisboa, Av. Prof. Gama Pinto, 1649-003 Lisboa, Portugal

3 DREAMS and Faculdade de Engenharia, Universidade Lusófona de Humanidades e Tecnologias, Av. Campo Grande 376, 1749-024 Lisboa, Portugal

4 Department of Bioengineering, Institute for Biotechnology and Bioengineering, Instituto Superior Técnico, Universidade de Lisboa, 1049-001 Lisboa, Portugal

5 Associate Laboratory i4HB-Institute for Health and Bioeconomy at Instituto Superior Técnico, Universidade de Lisboa, Av. Rovisco Pais, 1049-001 Lisboa, Portugal

6 Department of Pharmaceutical Sciences and Medicines, Faculty of Pharmacy, Universidade de Lisboa, Av. Prof. Gama Pinto, 1649-003 Lisboa, Portugal

* Correspondence: pedro.fernandes@ulusofona.pt; Tel.: +351-217515500

check for updates

Citation: Bié, J.; Sepodes, B.; Fernandes, P.C.B.; Ribeiro, M.H.L. Enzyme Immobilization and Co-Immobilization: Main Framework, Advances and Some Applications. Processes 2022, 10, 494. https://doi.org/10.3390/pr10030494

Academic Editor: Carla Silva

Received: 10 February 2022

Accepted: 27 February 2022

Published: 1 March 2022

Publisher's Note: MDPI stays neutral with regard to jurisdictional claims in published maps and institutional affiliations.

Copyright: (C) 2022 by the authors. Licensee MDPI, Basel, Switzerland. This article is an open access article distributed under the terms and conditions of the Creative Commons Attribution (CC BY) license (https:// creativecommons.org/licenses/by/ $4.0 /)$.

\begin{abstract}
Enzymes are outstanding (bio)catalysts, not solely on account of their ability to increase reaction rates by up to several orders of magnitude but also for the high degree of substrate specificity, regiospecificity and stereospecificity. The use and development of enzymes as robust biocatalysts is one of the main challenges in biotechnology. However, despite the high specificities and turnover of enzymes, there are also drawbacks. At the industrial level, these drawbacks are typically overcome by resorting to immobilized enzymes to enhance stability. Immobilization of biocatalysts allows their reuse, increases stability, facilitates process control, eases product recovery, and enhances product yield and quality. This is especially important for expensive enzymes, for those obtained in low fermentation yield and with relatively low activity. This review provides an integrated perspective on (multi)enzyme immobilization that abridges a critical evaluation of immobilization methods and carriers, biocatalyst metrics, impact of key carrier features on biocatalyst performance, trends towards miniaturization and detailed illustrative examples that are representative of biocatalytic applications promoting sustainability.
\end{abstract}

Keywords: immobilization; enzymes; multienzymes; microfluidic; pectinase; rhamnopyranosidase

\section{Introduction}

Enzymes have been used for millennia as tools to carry out a myriad of reactions under mild conditions, with high specificity and minimal environmental and health impacts, opposite to those that are associated with the use of chemical catalysts. Moreover, the price of enzymes has remained fairly stable over time, unlike that of several metal catalysts [1-3]. The industrial use of enzymes has thus been steadily increasing [4-9] in sectors ranging from agrochemicals [10] to textiles [11], through cosmetics [12,13], commodity chemicals [14,15], detergents [16,17], food [18,19], leather [20], paper and pulp [21], and pharmaceutical manufacture and as biopharmaceuticals [2,22]. However, despite their advantageous features, the potential of enzymes for industrial use has not yet been fully exploited. This can be ascribed to their low stability under harsh operational conditions, e.g., extreme $\mathrm{pH}$ environments, relatively high temperatures, presence of solvents, surfactants, or metal ions; low shelf-life; and most commonly, the difficulty in recovery and recycle $[6,23-26]$. This latter and most relevant drawback can be overcome with enzyme 
immobilization, an approach that decreases the overall process production economic cost, by enabling either continuous or repeated batch operation and facilitating downstream processing $[24,26,27]$. Moreover, immobilized enzymes typically display enhanced $\mathrm{pH}$ and thermal stabilities, and occasionally improved activity and selectivity, as compared to their corresponding free form counterparts [23,28-32]. Additionally, by enabling continuous operation, the use of immobilized enzymes is associated with high space time yields [33]. Finally, enzyme immobilization has been as an efficient tool to retrieve targeted enzymes from fermentation broths and cell lysates, therefore contributing to reducing the cost and complexity of enzyme production [34,35]. Overall, enzyme immobilization technology has been developed as a strategy to increase biocatalyst performance and reduce process costs $[22,26,29,31-34,36-38]$. Biocatalysis is pushing forth the design of bioprocesses and in a near future combinations of enzymes, namely in cascade reactions, will become even more important. The challenge of this review addresses the demands currently faced by immobilization: thus, it should contribute to the development and application of enzymes with several active centers, to the co-immobilization of enzymes and cofactors, as well as stabilization via different mechanism, improvement of enzyme activity (e.g., under drastic conditions), tune enzyme selectivity or specificity, reduce inhibitions, or even be coupled to enzyme purification. The review provides an updated overview of enzyme (co)-immobilization methods and carriers, their advantages and limitations and impact of several carrier features in biocatalyst performance, supported with recent illustrative examples; details on metrics to assess biocatalyst performance; a brief overview on the translation of enzyme immobilization to microfluidic environment; and detailed insight on selected case studies involving glucosidases and pectinases, which are involved in a vast array of processes whose application may be envisaged to be within the scope of sustainable and environmentally friendly production chain.

\section{Enzyme Immobilization: Drivers, Limitations, and Metrics}

Enzyme immobilization has been a relevant topic of research within the biocatalyst field over the last decades. The main drivers for immobilization include the quest for simple, clean downstream processing, enzyme stabilization and continuous/repeated use. Accordingly, a vast array of methodologies has been developed for enzyme immobilization. However, the implementation of the technology at large scale has been harder than expected, although several commercial processes only became feasible on account of enzyme immobilization [27]. An example of a succeeded immobilization process of engineered enzymes (galactose oxidase and kinases) is the synthesis of the antiviral islatravir by Merck \& Co. (Kenilworth, NJ, USA) and Codexis Inc. (Redwood City, CA, USA) [9].

Enzyme immobilization has nevertheless some limitations, namely: the economic cost of the carriers, the economic cost and complexity of immobilization methodologies plus the economic cost and complexity to dispose of the immobilized biocatalyst once activity is spent; activity decrease when compared with the free enzymes as an outcome of mass transfer limitations, enzyme inactivation due to immobilization procedures and fouling; and some empiricism still associated with immobilization methodologies [36-38]. Approaches to overcome these limitations have emerged. Thus, the introduction of nanostructured materials, with sizes akin to large biomolecules, as carriers for enzyme immobilization has been shown to minimize mass transfer hindrances. Additionally, the reduced particle size of the biocatalysts enhances surface area, thus increasing enzyme loading and ultimately improving activity. Finally, improved enzyme stability has also been reported [39-43]. Strategies allowing for controlled reversibility of immobilization have also been described [44-46]. Lastly, different methodologies have been suggested towards a more rational approach for enzyme immobilization, which include: detailed knowledge of the physical and chemical properties of both enzyme and carrier (e.g., distribution of hydrophobic and hydrophilic regions in the carrier and hydrophobic and polar regions in the surface of individual enzyme; carrier porosity, including pore size distribution, structure and volume carrier chemical and mechanical endurance of operational conditions); generation of databases 
and use of bioinformatics and other computational tools for improved characterization of enzymes and corresponding catalytic features; factorial planning; and protein engineering to enable a specific enzyme orientation on a carrier [37,47-51]. Overall, once optimized, enzyme immobilization is intended to provide a biocatalyst formulation that may lead to total turnover number (TTN), defined as the total moles of product produced per mole of enzyme over the entire lifetime of the enzyme, over either $10^{3}$ (for expensive products produced at small scale) or $5 \times 10^{5}-5 \times 10^{6}$ (for low-cost products/commodities), according to the thresholds required in industry [52-54]. TTN, together with turnover (TON), which provides the number of moles of substrate converted per mole of catalyst, and turnover frequency (TOF) that corresponds to TON over time, which for enzymatic catalysis is $\mathrm{k}_{\text {cat }}$, the Michaelis-Menten rate constant, are metrics commonly used to quantify biocatalyst performance, particularly in heterogenous catalysis [52,53,55]. Emphasis is often given to TTN, as it combines activity and stability features $[53,56]$, hence its use as a guideline in the development of industrial processes. Still, TTN can be biased unless determined under a standard, rigorous procedure [53,56]. Moreover, TTN is determined per mol of biocatalyst, which may be difficult to establish, particularly when commercial enzymes are used, as, depending on the application, some of these can be provided as relatively impure and crude mixtures to save costs $[53,57,58]$. To tackle the latter issue, the use of a productivity number, defined as the ratio of the mass of product formed per mass of catalysts prepared, has been introduced [53,55], where thresholds of either about up to $10^{4} \mathrm{~kg}$ of product per $\mathrm{kg}$ of immobilized enzyme or up to $10^{2} \mathrm{~kg}$ of product per $\mathrm{kg}$ of immobilized enzyme are required to meet the industrial demand for bulk commodity products or high-value pharma products, respectively [26]. Detailed insight on the implementation of standard metrics to assess biocatalysts performance can be found elsewhere $[15,48,49,51-53]$, but it is still a work in progress [1,53].

Besides these metrics, complementary parameters to characterize fully and unambiguously the immobilization process are required, which also abridges consistent terminology [52,59]. Such parameters, as well as the operational conditions under which they should be determined, have been presented and thoroughly discussed, in a recent comprehensive review [60]. Briefly, these bring along a clear distinction between protein and activity, and include: (i) protein immobilization yield, as the mass ratio of protein loading in the carrier to the protein in the starting solution. It relies on the determination of both the total protein concentration in the supernatant after immobilization and the total protein concentration in the stock solution. As often crude enzyme mixtures are used, the data gathered must be cautiously considered, as different proteins are likely to have different affinities towards the carrier [52,59,60]; (ii) immobilization yield, as the ratio of activity retained in the carrier to the activity in the starting solution, often referred to as activity yield. Although its use is under some scrutiny, immobilization yield has been widely used to establish the fraction of immobilized enzyme. It relies on the determination of the residual activity in the supernatant and the activity in the stock suspension at the end of the immobilization period, under standard conditions. The latter should be carried out with the assistance of a parallel blank experiment to tackle free enzyme deactivation throughout the immobilization procedure [52,59,60]; (iii) expressed activity, often termed activity recovery or recovery of activity, as the ratio of observed activity in the immobilized enzyme formulation and the activity in the stock solution. It relies on the determination of the total activities in immobilized enzyme formulation and in the stock solution, and it may be biased should enzyme deactivation occur throughout the immobilization procedure [59,60]; (iv) global enzyme activity yield, as the ratio of the observed activity in the immobilized enzyme formulation to the activity initially offered [60]. The widespread implementation of those parameters enables standardization and may favor the generation of a comparative database of enzyme immobilization procedures.

Nowadays the focus is mostly to get enzyme reactions to operate closer to industrial conditions. Such conditions require bioprocess performance metrics far from those noticed in the laboratory [61]. Although, evaluating catalytic activity (e.g., U/L, U stands for unit 
of enzyme activity, related to the amount of substrate consumed/product formed in a given timeframe and L stands for liter), specific activity (e.g., $\mathrm{U} / \mathrm{mg}$ enzyme, $\mu \mathrm{mol} / \mathrm{min}$ per mg enzyme), mass activity (e.g., U/g carrier), the productivity (e.g., g product/L reactor per hour), yield of product on biocatalyst (e.g., g product/g biocatalyst), yield of product on substrate (e.g., g product/g substrate), and product concentration (e.g., g product/L reactor) can be very valuable to benchmark processes and establish goals for progress [62]

\section{Immobilization Methods}

\subsection{Classification of Immobilization Methods and Their Key Features}

Most immobilization methods involve interaction with a solid carrier, but carrier-free methods have also been implemented (Figure 1) [25,27]. Carrier-based immobilization methods may involve either attachment to or containment inside a carrier. Attachment to a carrier can be carried out through physical or chemical interactions between the enzyme and the carrier $[29,31,36,48,63]$. In the former case, weak binding forces are involved, such as: (i) adsorption through hydrogen bonds, van der Waals forces and hydrophobic interactions (Figure 1a) [64]. Enzyme leakage is prone to occur, yet this can be minimized by coating the surface of the immobilized biocatalysts with a polymer. Moreover, this strategy may allow stabilization and tuning of operational selectivity, as recently highlighted by Gonçalves and co-workers using as bioconversion system the synthesis of xylose fatty esters from lauric and palmitic acids in 2-butanone using Lypozyme 435 as biocatalyst. Coating the carrier with polyethyleneimine $(2 \mathrm{kDa})$ promoted intermolecular crosslinkage of proteins, making enzyme leakage more difficult and enhancing operational stability. Additionally, the small size of polyethyleneimine enabled full coating of the immobilized enzyme and could assess the areas of the protein close to the carrier, increasing the thermal stability of the catalysts. Finally, mono-, di and tri-esters were synthesized when the coated biocatalyst opposite to non-coated biocatalyst was used. This behavior was tentatively associated by the authors to either conformational enzyme modifications induced by polyethyleneimine or to accumulation of acid molecules in the enzyme environment [65]; (ii) ionic interactions established between the carrier, viz. a charged resin and the oppositely charged sites on the enzyme surface (Figure 1b). Occasionally, adsorption and ionic interactions may co-exist, as observed in lipase immobilization to octyl-glutamic agarose [66]; (iii) affinity binding, where the carrier is typically functionalized with an affinity partner while the enzyme harbors the complementary partner. This strategy typically encompasses a recombinant, tagged enzyme, viz. a histidine tag, which bears high affinity to metal ions, viz. $\mathrm{Ni}^{2+}, \mathrm{Z}^{\mathrm{n} 2+}$ that are loaded in chelating groups on the surface of the carrier (Figure 1c). Given the relatively weak forces involved, hardly any changes in the native structure of the enzyme occur during immobilization, yet this immobilization method is prone to enzyme leakage due to shifts in the environmental conditions, viz., $\mathrm{pH}$, temperature or ionic strength. Eventually, enzyme leakage can be turned into an advantage under controlled condition, to allow carrier regeneration once the enzyme activity is spent. Adsorption and ionic binding are quite simple and low-cost methods, but non-specific. Affinity binding is highly selective, enables one pot purification and immobilization and allows oriented enzyme immobilization, yet it is costly [44,65-69]. Chemical attachment to the carrier involves covalent binding through amide, carbamate, ether or thio-ether bonds established between groups of suitable residues on the enzyme surface and on the carrier (Figure 1d $\mathrm{d}_{1}$ [36,67]. Binding to a carrier through reactive groups may also involve a spacer arm. A spacer arm is a chain of atoms, such as ethylenediamine or polyethylene glycol, comprised between reactive groups that positions the enzyme away from the solid carrier to which it is bound and is intended to decrease steric hindrance [70]. This approach, when used, has mostly involved covalent binding (Figure $\left.1 \mathrm{~d}_{2}\right)$ [70]. Given the strong binding, enzyme leakage is minimized and there is potential for significant stabilization of the immobilized formulation, particularly when multipoint attachment is involved. The latter has proved quite successful when highly epoxy-activated methacrylate-based carrier (commercially available) are used. Under suitable conditions, epoxy groups yield multiple aldehyde 
groups that can establish multipoint attachment in an oriented manner to the richest lysine region of the enzyme [71]. It has been suggested that the stability enhancement provided by covalent multipoint attachment was due to the resulting restrictions in enzyme mobility. This was experimentally validated recently by single molecule methods based on intramolecular Förster resonance energy transfer to monitor the immobilized dynamics of lipase A. The authors established that enzyme stability increased as the number of enzymecarrier attachments increased, as this correlated directly with enzyme rigidification. There was a trade-off, however, since the specific enzymes activity decreased, which was ascribed to a decay in the intrinsic dynamics of the folded state. The authors ultimately suggested that an optimum number for simultaneous high activity retention and stabilization exists but may vary depending on the enzyme [72].

On the other hand, loss of activity may occur during immobilization if covalent binding occurs in a relatively random manner, e.g., where enzyme residues that are prone to react with the active groups on the surface of the carrier become involved irrespective of their position in the enzyme molecule, which may lead to steric hindrance, modifications in native enzyme structure or compromised active site residues $[46,63,73,74]$. Also, covalent bonding may induce distortion of multimeric enzymes, although this drawback may be overcome through polymer coating of the carrier [75]. This was recently illustrated when pyrroline-5-carboxylate reductase formulation were incubated in the presence of polyethyleneimine during immobilization [76]. Finally, carrier regeneration is not feasible but for specific cases [77]. Physical containment within a carrier can be performed by either entrapment (Figure 1e) or encapsulation (Figure 1f). In the former the enzyme is retained within a polymeric network, whereas in the latter the enzyme is contained by a semi-permeable barrier. In either case, the carrier allows substrates and products to pass through but holds the enzyme. The immobilization method is mild, as there are no chemical interactions between enzyme and carrier, hence the risk of tampering with the native enzyme structure is minimized and the carrier material can be engineered to provide an optimal environment for the enzyme [29,36,67]. For instance, hydrogels provide a hydrophilic environment that can enhance enzymatic activity in a reaction medium involving organic solvents, namely when solvent sensitive enzymes are involved (e.g., dioxygenases) [78]. However, the risk of enzyme leakage, particularly in entrapment, is considerable and mass transfer limitations are often referred [36,65,70,79]. Detailed insight on recent achievements and foreseen developments involving enzyme immobilization in hydrogels can be found in a recently published review [80].

Carrier-free immobilization avoids the use of a large mass fraction ( 0.9 or above) of non-catalytic material in the immobilized biocatalysts formulation [81], hence prompting high space-time yields and productivities [67]. It mostly involves the use of cross-linked enzyme aggregates, CLEAs (Figure 1g). This self-immobilization method is performed through the precipitation of enzymes as physical aggregates induced by, e.g., a saturated ammonium sulfate solution. The aggregates are rendered permanently insoluble by crosslinking with an adequate chemical, most notably glutaraldehyde. CLEAs are typically sized within 5 to $50 \mu \mathrm{m}$ and can thus be recovered by filtration or centrifugation. Yet, separation can be further eased by incorporating magnetic particles (Figure 1h) or nanoparticles (Figure 1i) of, e.g., magnetite $\left(\mathrm{Fe}_{3} \mathrm{O}_{4}\right)$ or maghemite $\left(\gamma-\mathrm{Fe}_{2} \mathrm{O}_{3}\right)[25,26,67]$. The relatively reduced size CLEAs, as well as their reduced rigidity hampers their application in packed bed reactors, due to unacceptable pressure drop. This can be tackled by blending to/within a non-compressible carrier $[25,26,67,82]$. The latter approach is also illustrative of the combination of different immobilization methods to optimize the immobilized enzyme formulation [83]. Table 1 presents a brief overview on some advantages and limitations of different immobilization methods. 
Enzyme immobilization



Figure 1. Different enzyme immobilization techniques involving carrier bound $(\mathbf{a}-\mathbf{f})$ and carrier-free methods (g-i): (a) adsorption, involving hydrophobic interactions, hydrogen bonds and van der Waals forces between enzyme and carrier; (b) ionic binding, in the figure a negatively charged enzyme binds to a positively charged carrier; (c) affinity binding, in the figure a His-tagged enzyme selectively attaches to a metal ion activated carrier (dotted lines); $\left(\mathbf{d}_{\mathbf{1}}\right)$ covalent binding, in the figure an enzyme covalently binds (solid lines) to an activated carrier; $\left(\mathbf{d}_{\mathbf{2}}\right)$ covalent binding through a spacer arm, depicted as a zigzag line; (e) entrapment, in the figure an enzyme is restrained within a polymeric network (e.g., calcium alginate); (f) encapsulation, in the figure an enzyme is contained inside a semipermeable barrier (e.g., poly (lactide-co-glycolide, PLGA); (g) CLEAs, in the figure an enzyme and co-aggregate molecules are covalently bound (solid lines) through a crosslinker (e.g., glutaraldehyde); (h) magnetic CLEAs, as in (g) but the CLEAs formed by enzyme and co-aggregate are attached to a magnetic carrier; and (i) nano magnetic CLEAs, as in (g) but the CLEAs are formed by cross-linking enzyme, co-aggregate and magnetic nanoparticles. 
Table 1. A brief overview on some advantages and limitations of different immobilization methods.

\begin{tabular}{|c|c|c|c|}
\hline Immobilization Method & Advantages & Limitations & References \\
\hline $\begin{array}{l}\text { Adsorption: involves weak } \\
\text { interactions between enzyme and } \\
\text { carrier, e.g., van der Waals } \\
\text { intermolecular forces, hydrophobic } \\
\text { interactions }\end{array}$ & $\begin{array}{l}\text { Simple, low-cost preparation } \\
\text { No modification of the enzyme } \\
\text { required, active site typically not } \\
\text { affected, maximizes activity } \\
\text { retention. } \\
\text { Carrier regeneration most feasible }\end{array}$ & $\begin{array}{l}\text { Weak binding force, most prone to } \\
\text { enzyme leakage (most sensitive to } \\
\text { shifts in temperature and } \mathrm{pH} \text {, and } \\
\text { to strong hydrodynamic forces and } \\
\text { concomitant shear stress). Random, } \\
\text { non-specific immobilization. } \\
\text { Operational stability relatively poor } \\
\text { due to enzyme leakage }\end{array}$ & {$[66,84-87]$} \\
\hline $\begin{array}{l}\text { Ionic interaction: involves } \\
\text { electrostatic interactions between } \\
\text { oppositely charged residues in } \\
\text { carrier and enzyme }\end{array}$ & $\begin{array}{l}\text { Simple, low-cost preparation } \\
\text { Active site typically hardly affected, } \\
\text { high activity retention. } \\
\text { Intermediate binding force. Carrier } \\
\text { regeneration possible }\end{array}$ & $\begin{array}{l}\text { Less prone to enzyme leakage than } \\
\text { adsorption } \\
\text { Intermediate operational stability }\end{array}$ & {$[46,88-90]$} \\
\hline $\begin{array}{l}\text { Affinity binding: involves specific } \\
\text { interactions between } \\
\text { complementary molecules, e.g., } \\
\text { poly-histidine tagged enzyme-metal } \\
\text { ion activated carrier }\end{array}$ & $\begin{array}{l}\text { Oriented, well-controlled } \\
\text { immobilization } \\
\text { Highly specific } \\
\text { Carrier regeneration possible }\end{array}$ & $\begin{array}{l}\text { Cost and complexity } \\
\text { Specific groups are required in the } \\
\text { enzyme surface, complementary } \\
\text { binding agent needed }\end{array}$ & {$[44,68,69]$} \\
\hline $\begin{array}{l}\text { Covalent binding: involves strong } \\
\text { chemical bonds established } \\
\text { between carrier and enzyme } \\
\text { residues, e.g., through Schiff bases }\end{array}$ & $\begin{array}{l}\text { Strong binding } \\
\text { High stability } \\
\text { Most feasible for long term use }\end{array}$ & $\begin{array}{l}\text { Carrier regeneration largely } \\
\text { unfeasible. Complexity and cost. } \\
\text { Risk of activity loss during } \\
\text { immobilization }\end{array}$ & {$[36,91-94]$} \\
\hline $\begin{array}{l}\text { Entrapment/encapsulation: } \\
\text { involves physical retainment of the } \\
\text { enzyme within a polymeric } \\
\text { network (entrapment in e.g., } \\
\text { hydrogel) or enzyme containment } \\
\text { inside a semipermeable barrier } \\
\text { (encapsulation in e.g., a membrane) }\end{array}$ & $\begin{array}{l}\text { No chemical interaction between } \\
\text { enzyme and carrier, enzyme activity } \\
\text { site unhindered } \\
\text { Moderate cost and complexity } \\
\text { Multienzyme immobilization easy }\end{array}$ & $\begin{array}{l}\text { Diffusion limitations } \\
\text { Prone to enzyme leakage, } \\
\text { particularly low molecular wight } \\
\text { enzymes }\end{array}$ & {$[79,95-99]$} \\
\hline $\begin{array}{l}\text { CLEAs: carrier-free method, } \\
\text { involves chemical crosslinking of } \\
\text { enzyme molecules and } \\
\text { co-aggregates such as bovine serum } \\
\text { albumin, using bifunctional } \\
\text { compounds, e.g., glutaraldehyde }\end{array}$ & $\begin{array}{l}\text { Strong binding } \\
\text { Relatively simple preparation } \\
\text { Biocatalyst devoided of } \\
\text { non-catalytic material } \\
\text { Stabilization of multimers }\end{array}$ & $\begin{array}{l}\text { Activity loss during immobilization } \\
\text { Small pore size may result in poor } \\
\text { diffusion of high molecular weight } \\
\text { substrates. Compression and } \\
\text { cluster/clump formation during } \\
\text { recovery by } \\
\text { filtration/centrifugation, further } \\
\text { hindering diffusion }\end{array}$ & {$[25,100-104]$} \\
\hline $\begin{array}{l}\text { Magnetic-CLEAs: the same as } \\
\text { CLEAs but magnetic particles are } \\
\text { also crosslinked }\end{array}$ & $\begin{array}{l}\text { The same as for CLEAs plus eased } \\
\text { recovery of the biocatalyst using a } \\
\text { magnetic field }\end{array}$ & $\begin{array}{l}\text { Same as for CLEAs but } \\
\text { cluster/clump formation avoided } \\
\text { since recovery circumvents } \\
\text { filtration/centrifugation }\end{array}$ & {$[25,105-108]$} \\
\hline
\end{tabular}

Enzyme cross-linking upon adsorption to minimize leakage.

\subsection{Some Significant Carrier Features and Their Impact in Biocatalyst Performance \\ 3.2.1. Impact of the Carrier Hydrophilicity/Hydrophobicity}

Overall, the hydrophobic/hydrophilic nature of the carrier and interaction with hydrophilic and lipophilic residues distributed throughout the surface of the carrier has played a significant impact in the outcome of immobilization [51,109]. Thus, most enzymes, with lipase as a notable exception, display a negative impact on activity/stability upon immobilization on hydrophobic carriers [76,110-113]. This is the outcome of significant conformational changes observed (e.g., shift form $\alpha$-helical structure to $\beta$-sheet structure) as enzymes come close to hydrophobic surfaces/interfaces (e.g., gas), high salt concentrations or organic solvents, which may expose hydrophobic pockets to the medium [112,114-116]. A strategy presented to overcome such drawback, while taking advantage of epoxy-methacrylate carriers that strongly favor enzyme stabilization through 
multipoint covalent immobilization is hydrophilization of the carrier surface following enzyme immobilization. Hydrophilization was carried out by incubation of the immobilized enzyme preparation in aspartic acid, glycerin or lysine in the presence of 2-picoline borane. Proper manipulation of the microenvironment allowed noticeable stability of penicillin acylase and alcohol dehydrogenase formulations [74]. Contrarily to most of enzymes, lipases exhibit a significant amount of surface lipophilic residues that interact favorably with hydrophobic carriers, with increased stability/activity as outcome $[117,118]$. Additionally, the active center of lipases exhibits an uncommon flexibility; hence activity, selectivity and specificity can be properly tuned throughout immobilization by proper orientation of the enzyme or adjusting the degree of multipoint attachment [119]. Hydrophilic carriers may improve overall enzyme performance by improving intraparticle mass transport of substrates and products (e.g., in $\mathrm{O}_{2}$-related reactions) $[110,120]$. On the contrary, hydrophobic carriers (e.g., methacrylate-based) displayed significant mechanical stability, especially under dehydration conditions, but their use may negatively impact the outcome of some reactions if lipophilic molecules are involved (e.g., $\mathrm{O}_{2}$-related reactions) as these tend to stick to the carrier [110]. Grimaldi and co-authors further validated the positive impact of a moderate hydrophilic carrier for enzyme immobilization on the activity and thermal stability of alcohol dehydrogenase. However, the use of very hydrophilic carrier had the opposite effect on enzyme performance. The authors ascribed such behavior to the balance between destabilizing interprotein interactions and stabilizing protein-surface interaction. The mechanistic understanding was further supported by simulations using a model peptide contained in pores with different curvature surfaces. Ultimately, peptides immobilized inside concave, hydrophilic, surfaces displayed increased stability albeit only if pores were 3 to $4 \mathrm{~nm}$ larger than the hydrodynamic radius of the peptide. Still, if pore surface was very hydrophilic peptides were destabilized [121].

\subsubsection{Geometry and Pore Size and Morphology of the Carrier}

The impact of pore size in enzyme immobilization was assessed in a rather exhaustive and comprehensive manner by Bayne and co-authors [122]. Briefly, the authors reported a trend towards increased protein loading as pore diameter increased, within the 8 to $100 \mathrm{~nm}$ range. The authors also noticed that increased surface area enhanced protein loading although this was limited as small pore diameters (e.g., $2 \mathrm{~nm}$ ) were attained. It was also highlighted that the introduction of mesoporous materials, with pores sized within 2 to $50 \mathrm{~nm}$, thus in the range of the dimensions of most enzymes (e.g., 3 to $7 \mathrm{~nm}$ ) [123] favors enzyme immobilization. Chen and co-workers immobilized cellulase in two mesoporous silica carriers with pores sized $3.8 \mathrm{~nm}$ and $17.6 \mathrm{~nm}$. The former allowed lower protein loading yet higher activity as compared to the latter. It was suggested that more protein could be adsorbed in the larger pores, although desorption is favored, and the dense arrangement hampers conformational flexibility with concomitant loss of activity [124]. This overall pattern had also been previously reported by Takimoto and co-workers [125] while immobilizing cellulase in mesoporous materials with pore sizes ranging from 5.4 to $11 \mathrm{~nm}$. Kuo and co-workers also highlighted the relevance of pore morphology in enzyme performance. Mesoporous film-type carrier with a pore size of $6.0 \mathrm{~nm}$ a pore length around 60 to $100 \mathrm{~nm}$ displayed higher activity than foam type and rod-like mesoporous carriers. This pattern was ascribed to the highest accessibility of the enzyme to the environment provided by the film-type carrier [123]. Caldas and co-workers immobilized glucose oxidase, and enzyme with dimensions of roughly approximate dimension of $7.0 \times 5.5 \times 8.0 \mathrm{~nm}$ in silica graphite carriers with pores sized within 7 to $21 \mathrm{~nm}$. The largest pore size allowed the highest enzyme load, an outcome ascribed to more efficient diffusion of the large molecule, which was hindered in narrower paths. Accordingly, the highest enzyme activity was observed for the largest pore size [126]. Also related to the geometry of the carrier, Califano and co-workers shed further light on the effect of pore morphology on the catalytic performance of immobilized $\beta$-glucosidase. The enzyme was adsorbed in mesoporous silica nanoparticles with either central radial pores (pore size $\approx 12 \mathrm{~nm}$ ) or with disordered 
channel-like pores (pore size $\approx 8 \mathrm{~nm}$ ), in any case large enough to physically retain the enzyme. The authors established that the enzyme immobilized in the carrier with central radial pores displayed improved kinetics and thermal stability. This was related to the prevalent positioning of the enzyme in the interior of pore preventing the pores from being fully capped. Additionally, given the pore morphology, $\beta$-glucosidase settled in a such a manner that maximized interactions with the walls, which enhanced conformational rigidity [127]. Tadepalli and co-workers assessed the effect of size and curvature of the carrier particle on enzyme performance using as model system horse radish peroxidase (approximate dimensions $3.0 \times 6.5 \times 7.5 \mathrm{~nm}$ ) immobilized in gold nanoparticles with hydrodynamic diameters within 10 to $40 \mathrm{~nm}$. The authors established that smaller the particle, the lesser the changes in the secondary structure of the enzyme, which was attributed due to the high curvature of the particle. Moreover, the hydrodynamic diameter of the carrier after enzyme immobilization decreased concomitantly with diameter increase, better preserving the native structure in the smaller biocatalyst formulations. The effect of hydrodynamic diameter in kinetics was also addressed. The authors established that the turnover number decrease with particle size increase and was always lower than that of the free enzymes [128], which was associated with the effect of size and slower diffusion kinetics of the nanobiocatalyst as compared to the enzyme in solution. The Michaelis constant for the smallest immobilized biocatalyst was higher than that of the free enzyme, which was ascribed to poorer accessibility of the active site to the substrate molecules in the former, due to steric impediments caused by the neighboring enzymes on the nanoparticles. The increase in particle size led to a decrease in the Michaelis constant. As the free volume available on the nanobiocatalyst increased with the increase in the particle size and as the surface curvature decreases, the crowding of the enzymes was minimized, the access to the active site was enhanced and the Michaelis constant decreased.

While addressing the effect of pore size in biocatalyst performance, the influence of bulky substrates, e.g., starch, must also be considered. Typically, large pore size carriers (e.g., $70 \mathrm{~nm}$ to a few $\mu \mathrm{m}$ ) were used, yet Kahar and co-workers showed that $\alpha$-amylase immobilized amino-epoxide-activated supports with pores diameters within 40 to $60 \mathrm{~nm}$ ) allowed high enzyme activity and activity recovery [112]. The authors associated this behavior to the shallow nature of the pore, hence easing access and displaying improved diffusion for bulky starch to react with the bound enzyme, as compared to deep pores.

\subsubsection{Effect of Spacer Arm}

Kahar and co-authors highlighted the impact of the length of the spacer arms in biocatalyst performance [112]. Thus, shorter spacer arms resulted in steric hindrances or structural changes that led to misconformation of the enzyme substrate-binding pocket, with negative impact on biocatalyst activity, unlike what was observed with long spacer arms. Similar observations regarding the influence of spacer arms in the activity of immobilized enzyme formulations were also reported by Peng and co-workers when immobilizing glucose oxidase on polystyrene-glycidyl methacrylate) microspheres. These authors furthermore highlighted that the positive effect of longer spacer arms also results from preventing direct contact between enzyme molecules and the rough surface of the carrier [129]. Still, this pattern is not consensual. When immobilizing alcohol dehydrogenase on activated polyvinyl alcohol fibers through diamine-based spacers, Shinde and co-workers reported that the activity of the immobilized biocatalyst formulation decreased with the increase in spacer arm length. The authors associated this effect to either aggregation of the saturated amines in the aqueous medium or to both ends of longer diamines reacting with the surface of the carrier, hence decreasing the number of enzyme binding sites [130]. Alongside with chain length the hydrophobic/hydrophilic nature of the spacer arm also impacts on both initial activity and long-term stability of the immobilized enzyme formulation [131]. 


\subsubsection{Effect of Carrier Loading}

Carrier loading also impacts enzyme performance. Deposition of enzymes as a single monolayer prevents surface crowding and unwanted aggregation, optimizing interactions with substrate molecules [51,109], hence relatively low enzyme loadings on the carrier may result in high activity recovery [132], activity recovery of partially inactivated biocatalysts [133] and avoid diffusional restraints [118]. Still, the relation between enzyme loading and enzyme activity/stability is not always straightforward, as recently highlighted during the immobilization of Pseudomonas fluorescens lipase on octyl-agarose. Under given conditions, specific activity versus triacetin was higher at high enzyme loads than at low enzyme loads and stability was also enhanced at high enzyme loads. This effect was partially associated with enzyme-enzyme interactions, more noticeable at high enzyme loads, yet the authors also established that immobilization conditions (e.g., $\mathrm{pH}$, incubation in the presence of glycerin and of phosphate anions) impacted in differentiated manner in biocatalyst performance (e.g., activity over different substrates, stability) at high and low loads. Again, the authors stressed the relevance of enzyme-enzyme interactions and suggested that careful control of immobilization conditions may be used to tune biocatalyst functionality and stability [134]. Under the right conditions, enzyme aggregation can contribute to stabilization of immobilized enzyme formulations. This was recently highlighted, as bi-molecular aggregates of dimeric amine oxidase were produced by incubation in the presence of $30 \%$ polyethylene glycol and then immobilized by multipoint covalent attachment to glyoxyl-activated agarose carrier. The aggregated immobilized formulation was 49-fold more stable than isolated enzyme formulation and 200-fold more stable to thermal denaturation than the native enzyme [135].

\subsubsection{Carrier Composition and Immobilization Method}

Adjusting the properties of the carrier to fine tune the catalytic features of the immobilized biocatalyst was recently used by $\mathrm{Li}$ and co-workers when employing as enzyme Burkholderia cepacia lipase (BCL). $\mathrm{BCl}$ was immobilized in zeolitic imidazolate frameworks, where the ratio of the three linkers was varied according to a multivariate approach. This allowed to tune enzyme-framework interaction with hydrophilicity change in the microenvironment of the pores containing the enzyme. Thus, the hydrogen bonds of the framework could be adequately adjusted to be strong enough to interact with enzyme surface and generate an optimized conformation, albeit leaving untouched the structure of the buried catalytic triad. Ultimately, this allowed maintaining $99 \%$ enantiomeric excess of the products in several kinetic resolution reactions that were evaluated [136]. Within the same scope, Ruiz and co-workers, showed that depending on the type of carrier, and concomitantly immobilization method used and corresponding enzyme-enzyme and enzyme-surface interactions, the catalytic features of a psychrophilic lipase were modified. Irrespectively of the method, the thermal stability of the enzyme was clearly enhanced, as it could operate at $90{ }^{\circ} \mathrm{C}[137]$.

\subsection{Immobilization of Multimeric Enzymes}

A particularly complex issue that immobilization has helped to address is the stabilization of multimeric enzymes, which include several types of analytical/industrial relevant enzymes, e.g., aldolases, catalases, dehydrogenases, several galactosidases or oxidases. Inactivation of multimeric enzymes is typically triggered by the dissociation of the enzyme subunits or the loss of their correct assembly structure, issues to which mesophilic enzymes are particularly susceptible $[138,139]$. Some recently disclosed strategies to tackle these include: cyclization into a rigid form by connecting both the terminal ends and internal interface of subunits of an alcohol dehydrogenase, yielding a structure with enhanced thermal stability [140]; encapsulation of either glucose oxidase or of catalase contained in water in oil microemulsions in thermoresponsive chitosan-graft-poly( $\mathrm{N}$-isopropylacrylamide) gel, again producing a formulation with enhanced thermal stability [141]; multipoint covalent attachment of sucrose synthase on glyoxyl-agarose beads followed by coating with a bilayer 
of $25 \mathrm{kDa}$ polyethyleneimine and $25 \mathrm{kDa}$ dextran-aldehyde that also promotes cross linking of subunits and stabilize the quaternary structure, leading to a formulation significantly more stable (340-fold) than the non-coated formulation [142]. This strategy that combines immobilization of the multimeric enzyme complemented by post immobilization cross linking of sub-units has been suggested for several other enzymes [143]; mild multipoint covalent attachment of amine oxidase on glyoxyl-agarose beads, where, by careful control of the time of interaction between enzyme and carrier, a suitable trade-off between activity retention (50\%) and stability (350-fold increase) could be obtained [139].

Several thorough and comprehensive reviews focused on enzyme immobilization have been recently published, where updated information on the methodologies for enzyme immobilization and related issues, e.g., materials used for immobilization, physical and (bio)chemical characterization methods, impact on catalytic features of the enzyme and interface with reactor operation, can be found [30,36,57,67,70,144-155].

\section{Co-Immobilization of Enzymes}

Biocatalysis continues to evolve and provides an appealing route towards sustainable methods for organic synthesis and production. Multi-enzymatic (nano)systems find application in different fields such as biocatalysis or biomedical engineering and are considered as an alternative approach to produce pharmaceuticals, fine chemicals, food additives, biofuels, among others [70,156].

From a green chemistry approach the use of various biocatalytic steps is feasible, and it is desirable to avoid major changes in environmental conditions (e.g., temperature, $\mathrm{pH}$, pressure). Multi-step biocatalysis allows the integration of enzyme cascades in one pot reaction systems. In recent years, many new enzymes from the different classes have been made available, and protein engineering techniques pave the way for tuning enzyme properties to fit operation and scale-up requirements. Increasing efforts on improving processes now mean that examples from the laboratory start to match the target metrics set by economic needs. Other developments are in the area of flow biocatalysis and multistep biocatalysis, both of which also deliver improved sustainability. Developments in the benchmarking of processes using green chemistry and economic metrics also enable quantitative assessment of progress to be made [157].

Multi-enzymatic cascades thus allow the implementation of multi-step one-pot reactions, an approach that displays several advantages as compared to multi-pot ones such as: minimization of the accumulation of toxic or unstable intermediates and of the formation of side products, hence overall efficiency increases [158,159]; isolation of intermediate products is not required [160]; a lower number of process steps, hence production times are decreased and investment costs are lowered [161,162]; regeneration of costly co-factors (if involved) is achieved in-situ [163]; and equilibrium can be adequately shifted [46,164]. Nevertheless, some drawbacks are also associated, such as: the activity and stability of the enzymes involved may be unbalanced, because of different preferred environmental reaction conditions (e.g., temperature, $\mathrm{pH}$ ) and turnover frequency; cross-reactivity of the enzymes involved; long, complex and costly process development [161,165-170]. Co-immobilization of enzymes provides an approach to tackle some of these drawbacks.

Co-immobilization of enzymes, which act either sequentially or in a coordinated manner, involves the containment of multiple enzymes in the same space (either carrier or as CLEAs, hence denominated combi-CLEAs). This approach mimics Nature, where countless chemical reactions are catalyzed in tuned pathways within living cells [25,30,157,164,171-176]. Co-immobilization can lead to enhanced reaction yields as it allows the optimization of several parameters for each individual nanobiocatalyst, such as size, solubility, activity, or selectivity [164,174-177].

Thus, besides the well-established benefits of enzyme immobilization, co-immobilization may provide an individually suitable, compartmentalized micro-environment for each type of enzyme involved in the cascade, adequate spatial distribution and concentration of the enzymes involved in the cascade; close proximity of the enzymes, which decreases the dif- 
fusion path lengths of the reactants and may contribute to increase the overall reaction rate through substrate channeling. In substrate channeling, the product of an upstream cascade enzyme is directly moved to the active site of a contiguous downstream cascade enzyme, thus avoiding equilibration with the bulk phase [30,168-174]. Still, co-immobilization of enzymes should not be taken lightly, as discussed in detail by Arana-Peña and co-workers in a recently published comprehensive review. Briefly, co-immobilization for operation in one pot systems requires conditions such that all enzymes display proper activity and stability, a lack of which may render the option unfeasible; identification of compounds formed along the cascade that may have a deleterious effect on enzymes; identification of poorly soluble or labile compounds, as these may put an extra burden on process optimization. Taking these matters into consideration will narrow the range of enzymes and operational conditions feasible to target the intended goal and help balance the pros and cons of one-pot approach versus a multi- step conventional methodology [164]. Lack of suitable enzymes to fit the requirements for several cascade systems of interest prompted research in enzyme engineering for this field, as recently highlighted [175]. Within this scope, the design of artificial metalloenzymes, where a metal-containing moiety is anchored within a scaffold such as a protein or an oligonucleotide, combining the best features of enzymes and metal catalysts, is an interesting approach to incorporate a cascade in a single enzyme by creating multiple active sites: this approach has gained a renewed interest in recent years given the advances in protein engineering and organometallic synthesis that eased its implementation and the resulting catalysts have been used in a vast array of reactions, e.g., hydrogenations and carbon-carbon bond formation and bioremediation of hazardous compounds $[176,177]$. Other recent strategies to create enzymes with more than one active site besides artificial metal enzymes include the generation of enzymemetal nanoparticle hybrids and the creation of abiological active sites in a noncatalytic protein [178]. The former consists in the homogenous dispersion of metal nanoparticles in the enzyme, therefore providing multiple active sites while conserving the native activity and avoiding the complexity and time- consuming issues related to protein design and engineering and organometallic chemistry associated with the creation of artificial metalloenzymes [178-180]. The latter uses a protein scaffold, either generated de novo or assembled through recombination of fragments where active sites can be grafted. Although this is an elegant approach, able to deliver tailor made enzymes, it is quite complex and requires significant computational resources [178,181].

While addressing co-immobilization of enzymes some issues require particular attention. Thus, the size of the enzymes, unless a carrier-free approach is considered, as the pore diameter of a porous carrier will be conditioned by the size of the largest enzyme, with impacts on protein loading and access to the substrate, among others. If nonporous, nanomaterials are used as carriers, enzymes will simply distribute on the surface of the carrier. Again, if a carrier-free strategy is used, ordering the enzymes precisely in the carrier is hardly feasible $[157,164,169,170]$. However, in a porous support, if the rate of immobilization exceeds that of diffusion and is very fast, enzymes may be sequentially immobilized and distributed so the first enzyme immobilized will be located at the outermost area of the pore and the other enzymes will be successively immobilized towards the innermost area of the pore. Still, should the rate of immobilization of the different enzymes be still rapid but differ among them, in a mixture offered to the carrier, the enzymes will be distributed from the outermost to the innermost areas accordingly to the rate of immobilizations, from the faster immobilizing to the slower: the immobilization strategy must be the same for all enzymes, which favors the use of heterofunctional carriers, to fit the requirements of the different enzymes; the loading capacity of the carrier is limited for each enzyme [164]. This issue highlights the need for careful planning of the ratio of the enzymes to be used; finally, enzymes often have different stabilities. To tackle this, often an excess of the least stable enzyme is used to retain proper overall activity, albeit at the cost of the volumetric activity of the remaining enzymes. A potentially more effective alternative involves a strong binding of the most stable enzyme(s), that can be easily reused, and reversible 
immobilization of the least stable enzyme(s), so that they can be easily discarded when exhausted and then replenished [164].

Co-immobilization is highly suggested when the enzymes act synergistically, e.g., hydrolysis of polysaccharides, in full modification of fats and oils, in cascade reactions involving the sequential modification of a substrate to yield a significantly different product and in reactions that require a cofactor, which, besides the target enzyme, require a co-actor regenerating enzyme $[164,168,182]$. Co-immobilization is almost mandatory in systems where an intermediate compound is unstable, e.g., $\alpha$-oxoacids synthesis with amino acid oxidases through oxidative deamination of amino acids, where co-immobilization of the target enzyme and catalase has been shown to almost avoid the deleterious effects of the hydrogen peroxide formed as by-product; another example is the enantioselective hydrocyanation of aldehydes to produce enantiopure $\alpha$-hydroxynitriles through the combined use of a selective hydroxynitrile lyase and non-specific nitrilases [164,182]. Finally, coimmobilization of enzymes and co-factors is particularly appealing. Thus, given the high cost of co-factors coupling the main reaction to a second reaction catalyzed by a secondary enzyme enables the regeneration of the co-factor, regenerates the co-factor while shifting the equilibrium properly and minimizing the amount of co-factor $[120,164,183,184]$. On the other hand, co-immobilization of commercial enzyme cocktails is ill-advised. Thus, the ratio between the different enzymes optimized for the free form and for one cycle may not remain the same during immobilization and reuse. Purification of individual enzymes of the cocktail and ensuing co-immobilization is far from practical and is time consuming, there is no guarantee they will retain the same activity after immobilization and again the ratio between the enzymes may again be unbalanced. Further exhaustive insight on the advantages, limitations and considerations for the proper use (or not) of co-immobilization of enzymes can be found elsewhere [120,164,183,184].

Different strategies have been presented to implement co-immobilization of enzymes in either carrier-free or carrier bound form (Figure 2), in any case using the attachment methods (or a mixture of those) referred to in Figure 1 and related text $[157,171,173,185]$. Thus, enzymes can be co-immobilized in a random manner, which is the simplest strategy, and where different enzymes in the cascade are attached/entrapped/cross-linked. However, the control of immobilization pattern and ratio of immobilized enzyme is difficult $[171,174,186]$; positional co-immobilization, which allows to assemble the enzymes involved in an order concomitant to the reaction pathway and is often used to modify surfaces and channels to perform multi-enzymatic cascade reactions [187-190]; co-immobilization by compartmentalization aims to emulate the natural microenvironment of the enzymes involved in the cascade and significantly reduces mass transfer limitations and features short path lengths of intermediates. Compartmentalization has been achieved using diverse materials, such as polymers or hydrogels, and often, but not necessarily, combining entrapment/encapsulation and surface attachment [146,190-195].

Different enzyme co-immobilization techniques, like random co-immobilization by encapsulation, attachment to a surface, carrier free magnetic combi-CLEAs; positional coimmobilization by attachment to a surface; compartmentalization by entrapment/encapsula tion/attachment to a surface, are presented in Figure 2.

Detailed insight on the strategies and applications of co-immobilized enzymes can be found in recently published comprehensive reviews $[25,157,171,173,196]$. A wide array of materials, either of porous or non-porous nature, with a diversity of sizes and displaying different binding functionalities, has been developed for enzyme immobilization/coimmobilization (Table 2). This abridges "classic" materials, such as hydrogels or silica, and new materials, such as magnetic (nano)particles, mesoporous materials, ceramics, carbon nanotubes, graphene and derivatives, electrospun materials, metal-organic frameworks, or DNA nanostructures. This large portfolio enables the casuistic selection of the more adequate carrier for an intended goal. Despite many common features, different nanomaterials exhibit different effects on enzymatic structures or activities, depending mostly on 
the type and orientation of the enzymes, physical properties of nanomaterials, chemical groups attached to them and environmental conditions.

\section{Enzyme co-immobilization}

$\left(a_{1}\right)$



$\left(a_{2}\right)$

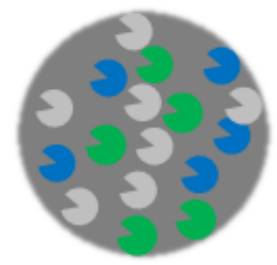

$\left(a_{3}\right)$

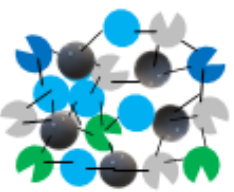

Enzyme 1, (a) to (c)

3 Enzyme 2, (a) to (c)

3 Enzyme 3, (a) to (c)

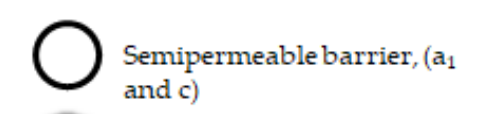

Enzyme carrier, $\left(\mathrm{a}_{2}\right)$

Co-aggregate (macromolecule with no catalytic activity, e.g., bovine serum albumin, BSA), ( $\left.a_{3}\right)$

Magnetic nanoparticle, $\left(a_{3}\right)$
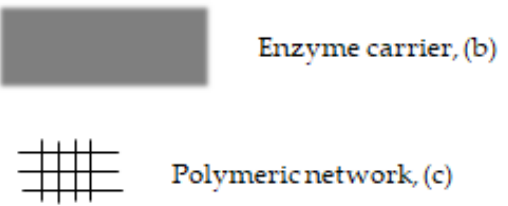

For further details see legend

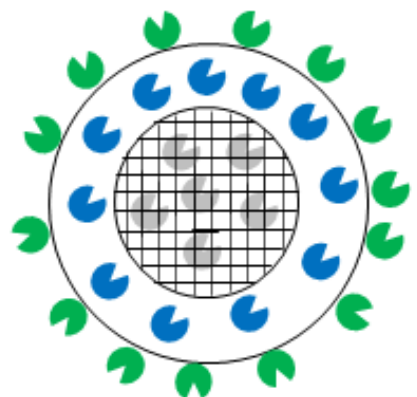

Figure 2. Different enzyme co-immobilization techniques: random co-immobilization by ( $\left.\mathbf{a}_{\mathbf{1}}\right)$ encapsulation, in the figure the enzymes distributed haphazardly are contained inside a semipermeable barrier; $\left(\mathbf{a}_{2}\right)$ attachment to a surface, in the figure the enzymes distributed haphazardly are attached to a solid carrier (attachment may involve adsorption, ionic binding or covalent binding); ( $\left.\mathbf{a}_{3}\right)$ carrier free magnetic combi-CLEAs, in the figure the enzymes, a co-aggregate and magnetic nanoparticles are covalently bound (solid lines) through a crosslinker (e.g., glutaraldehyde); (b) positional coimmobilization by attachment to a surface, in the figure the enzymes are attached to the carrier in an orderly manner to provide a proper sequence for the cascade reactions. Enzymes can be (covalently) bound to the inner walls of a capillary-type vessel or to polymers and DNA nanostructures; (c) compartmentalization, which mimics enzyme organization in cellular environments. In the figure the enzymes are spatially separated in compartments: in the inner compartment enzyme 1 is restrained inside a polymeric network. Encircling this inner compartment a capsule is formed, thus trapping enzyme 2 inside a semipermeable barrier. The outer surface of the capsule is activated, enabling the attachment of enzyme 3 (by e.g., covalent binding or affinity binding). Overall, in this latter case, co-immobilization involves entrapment/encapsulation/attachment to a surface.

Detailed information on the features, properties and application of the different materials used for multienzymes immobilization can be found in recently published reviews [148,173,197,198]. 
Table 2. A brief overview on some types of carriers for enzymes (co-)immobilization.

\begin{tabular}{|c|c|c|c|c|}
\hline Carrier Type & Main Features & Limitations & $\begin{array}{l}\text { Immobilization } \\
\text { Methods }\end{array}$ & Examples \\
\hline Inorganic: & $\begin{array}{l}\text { - Typically display high } \\
\text { thermal and mechanical } \\
\text { stability } \\
\text { - } \quad \text { High microbial resistance } \\
\text { - } \quad \text { Afford porosity and rigidity } \\
\text { Often convey constant pore } \\
\text { diameter to pore volume, } \\
\text { hence constant volume and } \\
\text { shape to the carrier }\end{array}$ & $\begin{array}{l}\text { Limited biocompatibility, } \\
\text { relatively low affinity to } \\
\text { biomolecules and narrow } \\
\text { range of geometrical } \\
\text { shapes available or that can } \\
\text { be created. Cross-linking } \\
\text { agent, e.g., such as } \\
\text { glutaraldehyde is typically } \\
\text { needed to covalently bind } \\
\text { the enzyme to the inorganic } \\
\text { carrier }\end{array}$ & $\begin{array}{l}\text { Adsorption/affinity/ionic } \\
\text { binding/covalent binding to } \\
\text { porous carriers; sol-gel } \\
\text { entrapment/encapsulation }\end{array}$ & $\begin{array}{l}\text { Carbon-based materials, } \\
\text { ceramics (e.g., kaolinite, } \\
\text { montmorillonite) [199], metal } \\
\text { oxides (e.g., alumina [200], } \\
\text { titanium oxide [201], zirconia } \\
\text { [202]), magnetic particles } \\
\text { (maghemite, magnetite) [203], } \\
\text { inorganic sol-gel, e.g., } \\
\text { silica-based sol-gel, [204] silica, } \\
\text { silica derivatives and siliceous } \\
\text { materials [205], porous glass } \\
\text { [206], pumice stone [207] }\end{array}$ \\
\hline Organic materials: & $\begin{array}{l}\text { Typically display biocompatibility } \\
\text { and affinity to biomolecules and } \\
\text { enable the design of diverse } \\
\text { geometry, thus tackling several } \\
\text { shortcomings of inorganic material. } \\
\text { Organic materials can be divided in } \\
\text { natural polymers (biopolymers) and } \\
\text { synthetic polymers. }\end{array}$ & & & \\
\hline Natural polymers & $\begin{array}{l}\text { Exhibit high biocompatibility, } \\
\text { biofunctionality, biostability, and } \\
\text { biodegradability } \\
\text { - } \quad \text { Available in diverse chemical } \\
\text { compositions and structures. } \\
\text { - Renewable, easy to obtain, } \\
\text { often as by-products of } \\
\text { various industries, hence } \\
\text { inexpensive } \\
\text { - Mild synthesis conditions }\end{array}$ & $\begin{array}{l}\text { Shifts in chemical } \\
\text { composition due to } \\
\text { seasonality and/or location } \\
\text { - Mechanical and/or } \\
\text { thermal stability } \\
\text { limited in some case, } \\
\text { albeit (partially) } \\
\text { superseded by } \\
\text { crosslinking }\end{array}$ & $\begin{array}{l}\text { Entrapment/encapsulation } \\
\text { most common due to easy gel } \\
\text { formation; affinity/ionic } \\
\text { binding/covalent binding to } \\
\text { carriers also used }\end{array}$ & $\begin{array}{l}\text { Agar-agar [208], agarose [209], } \\
\text { albumin [210], alginate [211], } \\
\text { carrageenan [212], cellulose, } \\
\text { chitin/chitosan [213], collagen } \\
\text { [214], gelatin [215], pectin [216], } \\
\text { Sepharose (crosslinked agarose) } \\
\text { [217], alginate/starch [217] }\end{array}$ \\
\hline Sinthetic polymers & $\begin{array}{l}\text { Polymeric chain assembled using } \\
\text { selected monomers to fit the } \\
\text { requirements of enzyme and process } \\
\text { where the catalyst will be used } \\
\text { - } \quad \text { Diversity of functional } \\
\text { groups, e.g., alkyl, amine, } \\
\text { carbonyl, carboxyl, epoxy, } \\
\text { hydroxyl, in the structure of } \\
\text { the polymer that ease enzyme } \\
\text { binding and polymer surface } \\
\text { functionalization } \\
\text { Tailored } \\
\text { hydrophobic/hydrophilic } \\
\text { nature of the carrier } \\
\text { Often available as highly } \\
\text { porous, ion-exchange resins }\end{array}$ & $\begin{array}{l}\text { Cost and complexity of } \\
\text { carrier development }\end{array}$ & $\begin{array}{l}\text { Entrapment/encapsulation } \\
\text { most common due to easy gel } \\
\text { formation; affinity/ionic } \\
\text { binding/covalent binding to } \\
\text { carriers also used }\end{array}$ & $\begin{array}{l}\text { Amberlite [218], polyacrylamide } \\
\text { (PAA) [219], polyamide (PA) } \\
\text { [220] polyaniline [221], } \\
\text { polystyrene (PS) [222], } \\
\text { polyurethane (PU) [223], } \\
\text { polyvinyl alcohol (PVA) [224] }\end{array}$ \\
\hline $\begin{array}{l}\text { Hybrid/composite } \\
\text { materials }\end{array}$ & $\begin{array}{l}\text { Combine organic and inorganic } \\
\text { parts to maximize their benefits and } \\
\text { minimize the shortcomings } \\
\text { - } \quad \text { Selected. contributors allow } \\
\text { control of composition, } \\
\text { morphology, functionality of } \\
\text { the carrier and pore } \\
\text { properties } \\
\text { Carrier tailormade to meet } \\
\text { the requirements of enzyme } \\
\text { and process where the } \\
\text { catalyst will be used } \\
\text { High control of the enzyme } \\
\text { immobilization process } \\
\text { Extremely versatile } \\
\text { - Stabilization of enzyme } \\
\text {-carrier interactions, high } \\
\text { retention of catalytic activity } \\
\text { Mechanical resistance and } \\
\text { stability under reaction } \\
\text { conditions }\end{array}$ & $\begin{array}{l}\text { Complexity and cost } \\
\text { New technology, stil with } \\
\text { many unknowns }\end{array}$ & $\begin{array}{l}\text { Immobilization methods: } \\
\text { adsorption/affinity/ionic } \\
\text { binding/covalent binding to } \\
\text { porous carriers; sol-gel } \\
\text { entrapment/encapsulation }\end{array}$ & $\begin{array}{l}\text { Calcium phosphate/gold [225], } \\
\text { metal organic frameworks [151] } \\
\text { (e.g., zeolitic imidazolate based } \\
\text { structures [226]), silica/carbon } \\
\text { nanotubes [227] } \\
\text { silica/titania/graphite [228] }\end{array}$ \\
\hline
\end{tabular}

\section{Microfluidics and (Co-)Immobilization}

In the last years, the field of microfluidics has been recognized as a major asset in many areas of research, as biology, biochemistry, biocatalysis, chemical analysis, clinical chemistry, environmental sciences, and physics, among others [229]. 
Microfluidics affords the opportunity to perform experiments at a small scale, with slight amounts of reagents and samples, with a high degree of parallelization, less expensive, showing in many cases better performance than at macroscale [230]. Nevertheless, at the microscale, both the physics of the fluidic system and the controlling parameters may be different and change more rapidly than in macrosystems [230].

Microfluidics refers to systems characterized by a width/height scale between $100 \mathrm{~nm}$ and $100 \mu \mathrm{m}$, handling volumes in the $\mu \mathrm{L}$ range, where fluid behavior differs from conventional flow mostly due to the reduced characteristic dimensions of the system $[229,230]$. Hence, flow in microfluidic systems is typically laminar which is quite predictable, therefore facilitating the mathematical modelling of these systems. Moreover, mass transport occurs only at molecular level (diffusion), which again results in relatively predictable kinetics [229,231]. Moreover, given the short diffusion length and the high specific surface area, mass and heat transfer can be significantly enhanced as compared to conventional systems [232,233]. Finally, and besides the ability to operate with minute volumes, microfluidic devices present the possibility of parallel operation and integration of monitoring and control tools [229,234,235].

From the combination of microfluidic devices with enzyme immobilization emerged microfluidic immobilized enzyme reactors, typically termed IMER, which typically display high enzyme-to-substrate ratio. Together with the advantageous features of the microfluidic environment, these reactors display high volumetric productivities. Residence times can be easily adjusted, and operation with hazardous chemicals, if needed, is less risky than in conventional vessels. Moreover, and unlike operation with classic packed column reactors where the size of the carrier must not exceed $100 \mu \mathrm{m}$ to avoid pressure drop issues, smaller carrier particles, down to nanoscale, can be used, again minimizing mass transfer limitations [67,190,236,237]. Accordingly, the use of microfluidic immobilized enzyme reactors for the development of both single-step and multi-step reaction systems has been increasing, as illustrated by recent reviews [57,67,190,238-240]. Enzymatic microreactors with multiple enzymes have been developed for fast small-scale biotransformations [237] and different (nano)supports and attachment techniques have been developed for multienzyme immobilization [236]. These improvements speed up the process development in an economically effective process. However, a well-characterized, robust, and easily integrated microreactor platform for some applications, as drug metabolism studies that does not compromise enzyme stability or kinetic properties is still missing. Recent research developments of immobilized microfluidic enzymatic reactors impacting biomedicine, bioanalysis, life sciences, biotechnological and biopharmaceutical applications have been established with interesting applications in the production of antibiotics, antivirals, antitumor drugs or drug delivery agents, among others [240].

\section{Some Applications}

In the last years, the intensification of bioactive ingredients in the food, pharmaceutical, and nutraceutical industries has increasingly fostered the introduction of efficient production processes. Enzyme-based processes have been a key part for the sustainable production of biobased goods, provided high levels of production, recovery, stability, and reusability of enzymes are achievable. As highlighted, the immobilization of (multi)enzymes has proved a major asset to ensure such requirements are fulfilled, thus contributing to the improvement of these bioprocesses. Two major case studies, involving either pectinases or glucosidases, are addressed in this review.

\subsection{Co-Immobilization of Pectinases}

\subsubsection{Pectinases: General Aspects, Classification and Applications}

Pectinases currently account for roughly $20 \%$ of the worldwide enzyme market [241]. These hydrolases degrade pectic substances, such as pectin polysaccharides, into smaller molecules like galacturonic acid. Pectic substances are high in molecular weight, which can exceed 200,000. Pectin is a structural acidic heteropolysaccharide rich in galacturonic acid 
with carboxyl groups esterified with methanol. It is present in cell walls of higher plants and is the reinforcing material between adjacent cells for the firmness and structure of the plant cellulose networks. Pectin concentration tops in the middle lamella and the cell wall. Not surprisingly, pectin is a major component in cereals, vegetables and fruits.

Pectinases are classified in four major groups: protopectinases, polygalacturonase (PGase), pectin lyase (PL), and pectinesterase [241,242].

Protopectinases, upon hydrolysis, degrade protopectin forming highly polymerized soluble pectin. This enzymatic reaction occurs at specific sites that have three or more no methylated galacturonic acid molecules, through hydrolysis of the glycosidic bond [243].

Polygalacturonase, one of the most used pectinases, degrades pectin into small molecules of galacturonic acid. It can be subclassified as endopolygalacturonases, which randomly attack the $\alpha-1,4$ linkages of the polysaccharide chain resulting in galacturonic acid oligomers, decreasing the substrate viscosity. Exopolygalacturonase I and II hydrolyze the digalacturonic acid from the nonreducing end of polygalacturonic acid [242].

Pectin lyase degrades pectin polymers through $\beta$-elimination, cleaving the glycosidic bond at the C-4 position, and simultaneously removing the hydrogen atoms at the C-5 position, thereby forming an unsaturated product containing a double bond [242].

Pectinesterases saponify the methyl ester groups of pectic substances, some attack the reducing chain, while others attack the non-reducing end resulting in free and esterified carboxyl groups. The activity of these enzymes makes the substrate, pectin, accessible for depolymerization [241,242,244-246]. Pectinesterases are used in several areas of industry, most notably in the food industry, where they are associated with: extraction, clarification and removal of pectin from fruit juices; maceration of vegetables to produce gums and smashes; and viscosity decrease in the liquid portion of mash in winemaking [245]. On the other hand, alkaline pectinases are used in the processing of textile fibers, coffee and tea fermentation, vegetable-oil extraction and treatment of paper pulp, among others [241,245].

More recently pectinases began to be used in the production of enzymatically derived pectin moieties in functional food preparation. Recent perspectives on the use of pectin and its derivatives as dietary fibers suggest enzymatic synthesis of the right oligomers from pectin for use in human nutrition [244,247].

\subsubsection{Pectinases: Sources and Production Methods}

Pectinases are widely distributed in higher plants, where they participate in the modification of pectinaceous materials during the natural ripening process of some fruits. Pectinases are biosynthesized by different sources such as bacteria, fungi, yeasts [245,248-251]. In recent years, microbial pectinases have been widely studied due to the requirement of highly productive strains and the cost-effective production of enzymes for industrial applications [251].

Almost all the commercial preparations of pectinases are produced by fungal species, mainly belonging to the Aspergillus genus. Among them, Aspergillus aculeatus stands out in the industrial production of pectinolytic enzymes [246].

Two main approaches are used in the production of pectinases by microorganisms: genetic manipulation and fermentation techniques. Various pectinolytic genes have been cloned and expressed successfully in a vast range of host organisms towards either homologous or heterologous expression with less energy input, economic cost and time. Recombinant DNA, tools such as cloning, expression mutation have been assessed for efficient enzyme production [250,251]. Pectinases have long been the focus of research aiming at obtaining large-scale expressions because of their significant potential for industrial applications.

Submerged fermentation $(\mathrm{SmF})$ is used in large scale production of pectinases. The yield depends on the strain and nutritional and environmental parameters. A wide spectrum of substrates can be used for the SmF production of pectinases, such as fruit processing wastes, fruit peels and residues from oil extraction. There are many reports available in the scientific literature with pectinases production under SmF conditions. SmF is privileged 
when enzymes are extracted from bacterial and yeast cultures, which necessitate high water potential $(>0.9)$ [241]. Bacterial cultures produce alkaline pectinases, whereas fungi and yeasts provide acidic pectinases [241,251].

The yield of pectinases depends on process variables such as the strain used, temperature, substrate nutritional sources and $\mathrm{pH}$. The substrates used are, mainly, orange peel, wheat bran, pectin, banana peel, rice bran, citrus pectin [241,251,252].

Submerged $(\mathrm{SmF})$ and solid-state fermentation (SSF) processes have been widely used for PGase production by different types of microorganisms. SSF is considered more suitable for fungi than for bacteria and yeast growth [241]. This is justified in terms of the natural habitat conditions for fungi (mainly soil), in contrast with those for bacteria or yeast, which are present in soils or liquid environments. The capability of fungi to grow under culture conditions with low water activity makes them more interesting for their use in SSF processes. Moreover, one of the major characteristics of this type of process is its low water content, used to avoid bacterial contamination by improving the fungal metabolism.

Microorganisms can be immobilized in inert polymeric solid supports (polyacrylamide, polyurethane and polyethylene glycol), natural materials (alginate, agar chitin, chitosan, carrageenan, collagen) [253]. Synthetic (polyacrylamide, polyurethane and polyethylene glycol), natural polymers are more promising supports. The use of immobilized cell cultures allows reusability, easy separation, lower risk of contamination, but although this technique reduces the costs of enzyme production the industrial use of this technique is still hindered [253-257].

\subsubsection{Immobilized Pectinase Formulations: Some Relevant Examples}

Pectinases are frequently used in soluble form. However, enzymes in this form are often unable to meet industrial requirements due to their short-term operational stability and because their recovery and reuse are difficult An interesting alternative to minimize these limitations is the immobilization, a procedure that allows for several advantages, among which are: (i) confinement or attachment of the enzyme in a defined space region while retaining its catalytic activity, (ii) exploitation of its activity repeatedly or continuously, (iii) enhancement of its stability, under either storage or operational conditions, (iv) easy separation from the product and (v) minimization of product contamination [246].

The co-immobilization of pectinases has been carried out in combination with different enzymes and supports. Some examples include the simultaneous, random, coimmobilization of:

(i) a-Amylase, pectinase, and cellulase in iron oxide magnetic nanoparticles functionalized with 3-aminopropyltriethoxysilane (APTES) followed by cross-linking with glutaraldehyde, which was used for the clarification of apple, pineapple, and grapes juices. Immobilization increased stability, namely the half-life increased by 2.4 -fold as compared to the free enzymes within 50 to $70^{\circ} \mathrm{C}$. The immobilized form was also more stable than the free enzymes when incubated in acidic environment ( $\mathrm{pH} 3.0$ to 6.0). Under optimized glutaraldehyde concentration, the activity recovery of immobilized enzymes peaked ( $\alpha$-amylase $89 \%$, pectinase $87 \%$, and cellulase $84 \%$ ) and encouraging reusability data was observed, as an average residual activity of $77 \%$ was obtained after eight successive batch runs [256]. The shelf life of free $\alpha$-amylase, cellulase, and pectinase was found to be 54,61 and $68 \%$, whereas the immobilized form retained 93,91 , and $89 \%$ residual activity, respectively (in 20 days). The increased stability of the immobilized form was ascribed to the stabilization of the tertiary structure of the enzymes as an outcome of the cross-linking action of glutaraldehyde [258].

(ii) Cellulase, pectinase, and xylanase were also immobilized in iron oxide magnetic nanoparticles functionalized with ATPES, followed by crosslinking with glutaraldehyde. Under optimized immobilization conditions, activity recovery of $85 \%, 81 \%$ and $76 \%$ were obtained for pectinase, cellulase and xylanase, respectively. Thermal stability was slightly enhanced within 55 to $75{ }^{\circ} \mathrm{C}$, as the half-life of the immobilized form was marginally higher (under 2-fold) than that of the. Immobilization also 
marginally enhanced the stability upon incubation under $\mathrm{pH} 4.0$ to 8.0 (up to 1.45-fold as compared to the respective free forms). As previously referred, the stabilization observed upon immobilization was ascribed to the cross-linking action of glutaraldehyde. The immobilized formulation depicted a residual activity slightly exceeding $85 \%$ after four consecutive batch runs. Afterwards, the residual activity decreased significantly to reach around $30 \%$ after eight consecutive batch runs. This pattern was tentatively associated with end-product inhibition and mechanical damage, which ultimately led to the deactivation of the immobilized enzymes. Immobilization also enhanced shelf-life, since after 36 days, the residual activity of xylanase, pectinase and cellulase increased 2.8-fold, 2.2-fold and 1.2-fold, respectively, as compared to the free form. The immobilized formulation was used in the extraction of piperine from black pepper, in the preparation of sugarcane cell protoplasts, and in the clarification of papaya juice. In all cases, the formulation was successfully used for at least three consecutive batch runs [259].

(iii) Pectinase and cellulase for the clarification of fruit juices, were immobilized either by covalent binding to glutaraldehyde activated iron oxide magnetic nanoparticles functionalized with APTES (Enz-MNP) or as magnetic CLEAs (MN-CLEAs), through precipitation of both magnetic particles and enzymes followed by cross-linking with glutaraldehyde. The half-life at $60{ }^{\circ} \mathrm{C}$ increased by an average of 2.4-fold and 1.4-fold for MN-CLEAs and Enz-MNP, respectively, as compared to the free enzymes. Again, stabilization was associated with chemical cross-linking involving glutaraldehyde, more so when MN-CLEAs are involved given the large number of multiples interactions between enzymes and enzymes and magnetic nanoparticles. Optimal temperature increased from $50{ }^{\circ} \mathrm{C}$ to $60^{\circ} \mathrm{C}$ upon immobilization. Moreover, immobilization allowed for higher activities at high temperatures, e.g., at $80^{\circ} \mathrm{C} \mathrm{MN}-\mathrm{CLEAs}$ and Enz-MNP displayed $84 \%$ and $67 \%$ of their maximal activities, respectively, as compared to $29 \%$ retained activity for the free form. The optimal $\mathrm{pH}$ was not changed by immobilization, yet at $\mathrm{pH}$ 3.0 MN-CLEA, displayed $80 \%$ of its maximal activity, compared with $30 \%$ of the free form. On the other hand, the free form depicted higher activities with $\mathrm{pH} 4.0$ to 6.0. This behavior was associated with the ionization state of the microenvironment surrounding the active site due to the magnetic nanoparticles and/or glutaraldehyde. Recovered activities of 33.6\% and 5.6\% were observed for MN-CLEAs and Enz-MNP, respectively. Again, the vast multipoint interactions involving glutaraldehyde, enzymes and nanoparticles was suggested to have allowed a more assorted fraction of all enzymes than those allowed in Enz-MNP, hence increasing the activity of MN-CLEAs. Immobilization leading to Enz-MNP was suggested to have proceeded in such a manner that favorer pectinase binding over cellulase, therefore hampering overall catalytic activity. MN-CLEAs also outperformed Enz-MNP when operational stability was assessed. Hence, the former formulation displayed $10 \%$ residual activity after eight consecutive batch cycles, whereas the latter was fully exhausted after seven consecutive batch runs. This behavior was tentatively ascribed to several factors, e.g., enzyme leaching, thermal induced denaturation, mechanical or/and hydrodynamic stress. On the other hand, the shelf-life of the two immobilized formulation did not differ. Thus, the catalytic activity of both formulations remained unchanged for 30 days [256].

(iv) Commercial preparations of pectinase $\left(\right.$ Pectinex $\left.^{\circledR}\right)$ and cellulase (Celluclast ${ }^{\circledR}$ ) were immobilized in iron oxide magnetic nanoparticles functionalized with 3-aminopropyltrie thoxysilane (APTES) followed by cross-linking with glutaraldehyde. Immobilization led to around 2.5-fold average increase in half-life within 50 to $70{ }^{\circ} \mathrm{C}$ [260]. Stabilization of the immobilized formulation was again related to glutaraldehyde cross-linking. Under optimized immobilization conditions, recovered activities of $92 \%$ and $87 \%$ were reported for pectinase and cellulase, respectively. The formulation displayed high operational stability, since $80 \%$ residual activity was reported after 10 consecutive batch runs. The immobilized formulation was for the extraction of antioxidant from 
real fruit waste peels, orange (Citrus sinensis), mango (Mangifera indica), and banana (Musa acuminate) [258].

(v) Pectinase and cellulase in ferrite-based nanoparticles, functionalized with the agent, 3-aminopropyl triethoxysilane (APTES)/glutaraldehyde present a stability of the half-life of magnetic nanobiocatalyst increased by almost 3 folds as compared to the free form that confirmed enhanced thermal stability ranging from 30 to $60{ }^{\circ} \mathrm{C}$, the enzyme loading of the xylanase ( $80 \%$ ) was observed, the reusability, as residual activity of immobilized biocatalyst was found to be $50 \%$ after six consecutive cycles, the shelf life of the immobilized enzyme retained $90 \%$ residual activity over 30 days, the application was in the extraction of lycopene from tomato peels [261-263]; $\alpha$-amylase, pectinase and cellulase using covalent co-immobilization with use of glutaraldehyde as crosslinker, originated two fold increment in half-life, enhanced $\mathrm{pH}$ stability, and reusability for eight reaction cycles, the applicability is in fruit juice clarification [264,265].

\subsection{Co-Immobilization of Glucosidases}

Rhamnopyranosidase is an enzyme complex of $\beta$-glucosidase and $\alpha$-L-rhamnosidase, that catalyzes the cleavage of the glycosidic bond of sugars, rhamnose and glucose, from compounds, including precursors of the aromatic components present in glycosidic form [266]. This heterodimer of $168 \mathrm{kDa}$ is characterized by the presence of Asp567 and Glu841 in their active site [267]. Rhamnopyranosidase is produced by yeasts, fungi and bacteria [266,268].

Rhamnopyranosidase shows high potential in glycocompounds production, with applications in food and pharmaceutical industries [266,268]. These applications include citrus-juice processing, namely in the debittering of some juices (e.g., grapefruit juice), naringin hydrolysis, and reduction of haze by hydrolysis of hesperidin (e.g., in orange juices) and pectins containing rhamnose [268-273]. Another application is the aromatization of fruit juices (passion fruit, apple, apricot, peach, tomato, pineapple, cherry, pear, papaya, banana) musts and wines [274]. For the reduction of bitterness, rhamnopyranosidase acts by degradation of naringin to its aglycone, naringenin.

The co-immobilization of $\beta$-glucosidase with other(s) enzyme(s) has been performed for different applications. Some examples include the simultaneous co-immobilization of: (i) endo-glucanase, exoglucanase, and $\beta$-glucosidase in gold-doped magnetic silica nanoparticles for the degradation of cellulose [270]; (ii) endoglucanase, exoglucanase, and $\beta$-glucosidase using site-specific immobilization of bacterial outer membrane vesicles acting as spheroid nanoparticles with an increase of 23-fold enhancement in glucose production compared with free enzymes for hydrolysis of cellulose [275].

\section{Conclusions and Future Work}

The use of biocatalysts in production processes has been steadily increasing, more so with the growing public awareness of the need for sustainable and eco-friendly approaches to produce/process goods. The immobilization of enzymes, a strategy first introduced in large scale production in the 1960s, has been shown to be a tool that can contribute significantly towards the aforementioned major goals. Initially involving single enzyme immobilization, latter evolving to multi-enzyme co-immobilization, this strategy provides a unique way to diversify modes of operation, enable the repeated use of the biocatalyst, improve the latter stability and eventually modulate its activity. Aiming at a proper quantification of the performance of immobilized biocatalysts, several metrics have been gradually introduced. These are particularly appealling, since no single method of immobilization has emerged as the most appropriate, rather several methods have been presented, each with their unique advantages and downsides. In recent years significant efforts have been made to introduce more reliable immobilization methods, novel materials and rational immobilization techniques. Besides biochemical insights, these developments owe significantly to the increased knowledge on the nature, physical-chemical and geometric features 
of the carriers and on enzyme-enzyme and enzyme-carrier interactions. Combined with detailed insight on the features of enzymes involved in cascades and the kinetic nature of the latter, immobilizing enzyme cascades has been successfully implemented. All these developments in enzyme immobilization have been successfully implemented in microfluidic devices, tools that allow for faster and cost-effective process development and process intensification. Illustrative examples of the recent findings in enzyme immobilization were highlighted using as case studies applications involving glucosidases and pectinases. It is expected that miniaturization within the scope of enzyme-catalyzed biotransformations will become increasingly relevant and widespread, particularly through improvements in the area of flow biocatalysis and multienzymes biocatalysis, will provide improved sustainability in the bioprocess. The integration of databases on biocatalytic reactions and their characteristics into machine-assisted high-throughput process development is also foreseen. Additionally, the development of new (bio)materials design systems, incorporating computational design and streamlined prototyping of material properties will be important in speeding up functional material design and improvement.

Author Contributions: All authors have substantially contributed to the conceptualization, methodology, resources, writing - original draft preparation, writing - review and editing. All authors have read and agreed to the published version of the manuscript.

Funding: This research was funded by FCT_FOUNDATION FOR SCIENCE AND TECHNOLOGY, I.P., through National Funds, under the projects UID/DTP/04138/2021 and UID/BIO/04565/2020.

Conflicts of Interest: The authors declare no conflict of interest. The funders had no role in the design of the study; in the collection, analyses, or interpretation of data; in the writing of the manuscript, or in the decision to publish the results.

\section{References}

1. Sheldon, R.A. Metrics of Green Chemistry and Sustainability: Past, Present and Future. ACS Sustain. Chem. Eng. 2018, 6, 32-48. [CrossRef]

2. Adams, J.P.; Brown, M.J.B.; Diaz-Rodriguez, A.; Lloyd, R.C.; Roiban, G.D. Biocatalysis: A Pharma Perspective. Adv. Synth. Catal. 2019, 361, 2421. [CrossRef]

3. Heckmann, C.M.; Paradisi, F. Looking Back: A Short History of the Discovery of Enzymes and How They Became Powerful Chemical Tools. ChemCatChem 2020, 12, 6082-6102. [CrossRef]

4. Choi, J.M.; Han, S.S.; Kim, H.S. Industrial applications of enzyme biocatalysis: Current status and future aspects. Biotechnol. Adv. 2015, 33, 1443-1454. [CrossRef] [PubMed]

5. Singh, R.; Kumar, M.; Mittal, A.; Mehta, P.K. Microbial enzymes: Industrial progress in 21st century. 3 Biotech 2016, 6, 174. [CrossRef] [PubMed]

6. Chapman, J.; Ismail, A.E.; Dinu, C.Z. Industrial Applications of Enzymes: Recent Advances, Techniques, and Outlooks. Catalysts 2018, 8, 238. [CrossRef]

7. Wackett, L.P. Microbial industrial enzymes: An annotated selection of World Wide Web sites relevant to the topics in microbial biotechnology. Microb. Biotechnol. 2019, 12, 405-406. [CrossRef]

8. Abdelraheem, E.M.M.; Busch, H.; Hanefeld, U.; Tonin, F. Biocatalysis explained: From pharmaceutical to bulk chemical production. React. Chem. Eng. 2019, 4, 1878-1894. [CrossRef]

9. Wu, S.; Snajdrova, R.; Moore, J.C.; Baldenius, K.; Bornscheuer, U.T. Biocatalysis: Enzymatic Synthesis for Industrial Applications. Angew. Chem. Int. Ed. Engl. 2021, 60, 88-119. [CrossRef] [PubMed]

10. Aleu, J.; Bustillo, A.J.; Hernandez-Galan, R.; Collado, I.G. Biocatalysis Applied to the Synthesis of Agrochemicals. Curr. Org. Chem. 2006, 10, 2037-2054. [CrossRef]

11. Madhu, A.; Chakraborty, J.N. Developments in application of enzymes for textile processing. J. Clean. Prod. 2017, 145, 114-133. [CrossRef]

12. Sá, A.G.A.; de Meneses, A.C.; de Araújo, P.H.H.; de Oliveira, D. A review on enzymatic synthesis of aromatic esters used as flavor ingredients for food, cosmetics and pharmaceuticals industries. Trends Food Sci. Technol. 2017, 69, 95-105. [CrossRef]

13. Yarosh, D.B.; Rosenthal, A.; Moy, R. Six critical questions for DNA repair enzymes in skincare products: A review in dialog. Clin. Cosmet. Investig. Dermatol. 2019, 12, 617-624. [CrossRef]

14. Woodley, J.M. Towards the sustainable production of bulk-chemicals using biotechnology. New Biotechnol. 2020, 59, 59-64. [CrossRef]

15. Gürkök, S. Microbial enzymes in detergents: A review. Int. J. Sci. Eng. Res. 2019, 10, 75-81.

16. Al-Ghanayem, A.A.; Joseph, B. Current prospective in using cold-active enzymes as eco-friendly detergent additive. Appl. Microbiol. Biotechnol. 2020, 104, 2871-2882. [CrossRef] [PubMed] 
17. Al-Hemaid, F.; Chandrasekaran, M. Enzymes in Processing of Nutraceuticals. In Enzymes in Food and Beverage Processing; Chandrasekaran, M., Ed.; CRC Press: Boca Raton, FL, USA, 2015; pp. 401-423.

18. Raveendran, S.; Parameswaran, B.; Ummalyma, S.B.; Abraham, A.; Mathew, A.K.; Madhavan, A.; Rebello, S.; Pandey, A. Applications of Microbial Enzymes in Food Industry. Food Technol. Biotechnol. 2018, 56, 16-30. [CrossRef] [PubMed]

19. Khambhaty, Y. Applications of enzymes in leather processing. Environ. Chem. Lett. 2020, 18, 747-769. [CrossRef]

20. Singh, G.; Capalash, N.; Kaur, K.; Puri, S.; Sharma, P. Enzymes: Applications in pulp and paper industry. In Agro-Industrial Wastes as Feedstock for Enzyme Production: Apply and Exploit the Emerging and Valuable Use Options of Waste Biomass; Dhillon, G., Kaur, S., Eds.; Academic Press: San Diego, CA, USA, 2016; pp. 157-172.

21. Meghwanshi, G.K.; Kaur, N.; Verma, S.; Dabi, N.K.; Vashishtha, A.; Charan, P.D.; Purohit, P.; Bhandari, H.; Bhojak, N.; Kumar, R. Enzymes for pharmaceutical and therapeutic applications. Biotechnol. Appl. Biochem. 2020, 67, 586-601. [CrossRef]

22. Rodrigues, R.C.; Ortiz, C.; Berenguer-Murcia, A.; Torres, R.; Fernandez-Lafuente, R. Modifying enzyme activity and selectivity by immobilization. Chem. Soc. Rev. 2013, 42, 6290-6307. [CrossRef]

23. Sheldon, R.A.; Woodley, J.M. Role of Biocatalysis in Sustainable Chemistry. Chem. Rev. 2018, 118, 801-838. [CrossRef] [PubMed]

24. Silva, C.; Martins, M.; Jing, S.; Fu, J.; Cavaco-Paulo, A. Practical insights on enzyme stabilization. Crit. Rev. Biotechnol. 2018, 38, 335-350. [CrossRef] [PubMed]

25. Sheldon, R.A. CLEAs, Combi-CLEAs and 'Smart' Magnetic CLEAs: Biocatalysis in a Bio-Based Economy. Catalysts 2019, 9, 261. [CrossRef]

26. Basso, A.; Serban, S. Industrial applications of immobilized enzymes-A review. Mol. Catal. 2019, 479, 110607. [CrossRef]

27. Romero-Fernández, M.; Paradisi, F. General overview on immobilization techniques of enzymes for biocatalysis. In Catalysts Immobillization; Benaglia, M., Puglisi, A., Eds.; John Wiley \& Sons, Ltd.: New York, NY, USA, 2019; pp. 409-435.

28. Thompson, M.P.; Derrington, S.R.; Heath, R.S.; Porter, J.L.; Mangas-Sanchez, J.; Devine, P.N.; Truppo, M.D.; Turner, N.J. A generic platform for the immobilisation of engineered biocatalysts. Tetrahedron 2019, 75, 327-334. [CrossRef]

29. Federsel, H.J.; Moody, T.S.; Taylor, S. Recent Trends in Enzyme Immobilization-Concepts for Expanding the Biocatalysis Toolbox. Molecules 2021, 26, 2822. [CrossRef]

30. Sheldon, R.A.; Brady, D. Streamlining Design, Engineering, and Applications of Enzymes for Sustainable Biocatalysis. ACS Sustain. Chem. Eng. 2021, 9, 8032-8052. [CrossRef]

31. Taheri-Kafrani, A.; Kharazmi, S.; Nasrollahzadeh, M.; Soozanipour, A.; Ejeian, F.; Etedali, P.; Mansouri-Tehrani, H.A.; Razmjou, A.; Yek, S.M.G.; Varma, R.S. Recent developments in enzyme immobilization technology for high-throughput processing in food industries. Crit. Rev. Food Sci. Nutr. 2021, 61, 3160-3196. [CrossRef] [PubMed]

32. Nidetzky, B.; Bolivar, J. Continuous biocatalytic processing and synthesis: Variations on a theme of "flow chemistry". Chim. Oggi-Chem. Today 2015, 33, 20-24.

33. Bergquist, P.L.; Siddiqui, S.; Sunna, A. Cell-Free Biocatalysis for the Production of Platform Chemicals. Front. Energy Res. 2020, 8, 193. [CrossRef]

34. Barbosa, O.; Ortiz, C.; Berenguer-Murcia, Á.; Torres, R.; Rodrigues, R.C.; Fernandez-Lafuente, R. Strategies for the one-step immobilization-purification of enzymes as industrial biocatalysts. Biotechnol. Adv. 2015, 33, 435-456. [CrossRef]

35. Cai, L.; Chu, Y.; Liu, X.; Qiu, Y.; Ge, Z.; Zhang, G. A novel all-in-one strategy for purification and immobilization of $\beta-1,3-x y l a n a s e$ directly from cell lysate as active and recyclable nanobiocatalyst. Microb. Cell Factories 2021, 20, 37. [CrossRef] [PubMed]

36. Mohamad, N.R.; Marzuki, N.H.C.; Buang, N.A.; Huyop, F.; Wahab, R.A. An overview of technologies for immobilization of enzymes and surface analysis techniques for immobilized enzymes. Biotechnol. Biotechnol. Equip. 2015, 29, 205-220. [CrossRef] [PubMed]

37. Sheldon, R.A. Enzyme Immobilization: The Quest for Optimum Performance. Adv. Synth. Catal. 2007, 349, 1289-1307. [CrossRef]

38. Romero-Fernández, M.; Paradisi, F. Protein immobilization technology for flow biocatalysis. Curr. Opin. Chem. Biol. 2020, 55, 1-8. [CrossRef]

39. Hwang, E.T.; Gu, M.B. Enzyme stabilization by nano/microsized hybrid materials. Eng. Life Sci. 2013, 13, 49-61. [CrossRef]

40. Bilal, M.; Iqbal, H.M.N. Chemical, physical, and biological coordination: An interplay between materials and enzymes as potential platforms for immobilization. Coord. Chem. Rev. 2019, 388, 1-23. [CrossRef]

41. An, J.; Li, G.; Zhang, Y.; Zhang, T.; Liu, X.; Gao, F.; Peng, M.; He, Y.; Fan, H. Recent Advances in Enzyme-Nanostructure Biocatalysts with Enhanced Activity. Catalysts 2020, 10, 338. [CrossRef]

42. Correa, S.; Ripoll, M.; Jackson, E.; Grazú, V.; Betancor, L. Stabilization of $\beta$-Glucuronidase by Immobilization in Magnetic-Silica Hybrid Supports. Catalysts 2020, 10, 669. [CrossRef]

43. Singh, N.; Dhanya, B.S.; Verma, M.L. Nano-immobilized biocatalysts and their potential biotechnological applications in bioenergy production. Mater. Sci. Energy Technol. 2020, 3, 808-824. [CrossRef]

44. Bolivar, J.M.; Nidetzky, B. Positively Charged Mini-Protein Zbasic2 as a Highly Efficient Silica Binding Module: Opportunities for Enzyme Immobilization on Unmodified Silica Supports. Langmuir 2012, 28, 10040-10049. [CrossRef]

45. Rueda, N.; Albuquerque, T.L.; Bartolome-Cabrero, R.; Fernandez-Lopez, L.; Torres, R.; Ortiz, C.; Dos Santos, J.C.S.; Barbosa, O.; Fernandez-Lafuente, R. Reversible Immobilization of Lipases on Heterofunctional Octyl-Amino Agarose Beads Prevents Enzyme Desorption. Molecules 2016, 21, 646. [CrossRef] [PubMed]

46. Mateo, C.; Pessela, B.C.C.; Fuentes, M.; Torres, R.; Ortiz, C.; López-Gallego, F.; Betancor, L.; Alonso-Morales, N.; Guisan, J.M.; Fernandez-Lafuente, R. Very Strong but Reversible Immobilization of Enzymes on Supports Coated with Ionic Polymers. In 
Immobilization of Enzymes and Cells. Methods and Protocols; Guisan, J., Bolivar, J., López-Gallego, F., Rocha-Martín, J., Eds.; Humana: New York, NY, USA, 2020; Volume 2100, pp. 129-141.

47. Del Monte-Martínez, A.; Cutiño-Avila, B.V. Rational design of immobilized lipases and phospholipases. Methods Mol. Biol. 2012, 861,343-382. [PubMed]

48. Sastre, D.E.; Reis, E.A.; Marques Netto, C.G.C. Strategies to rationalize enzyme immobilization procedures. Methods Enzymol. 2020, 630, 81-110. [PubMed]

49. Roura Padrosa, D.; Marchini, V.; Paradisi, F. CapiPy: Python based GUI-application to assist in protein immobilization. Bioinformatics 2021, 18, btab030. [CrossRef] [PubMed]

50. Range, J.; Halupczok, C.; Lohmann, J.; Swainston, N.; Kettner, C.; Bergmann, F.T.; Weidemann, A.; Wittig, U.; Schnell, S.; Pleiss, J EnzymeML-a data exchange format for biocatalysis and enzymology. FEBS J. 2021. [CrossRef]

51. Secundo, F. Conformational changes of enzymes upon immobilisation. Chem. Soc. Rev. 2013, 42, 6250-6261. [CrossRef] [PubMed]

52. Liese, A.; Hilterhaus, L. Evaluation of immobilized enzymes for industrial applications. Chem. Soc. Rev. 2013, 42, 6236-6249. [CrossRef] [PubMed]

53. Dias Gomes, M.; Woodley, J.M. Considerations when Measuring Biocatalyst Performance. Molecules 2019, 24, 3573. [CrossRef]

54. Velasco-Lozano, S. Immobilization of Enzymes as Cross-Linked Enzyme Aggregates: General Strategy to Obtain Robust Biocatalysts. In Immobilization of Enzymes and Cells. Methods in Molecular Biology; Guisan, J., Bolivar, J., López-Gallego, F., Rocha-Martín, J., Eds.; Humana: New York, NY, USA, 2020; Volume 2100, pp. 345-361.

55. Bommarius, A.S.; Paye, M.F. Stabilizing biocatalysts. Chem. Soc. Rev. 2013, 42, 6534-6565. [CrossRef] [PubMed]

56. Bommarius, A.S. Biocatalysis: A Status Report. Annu. Rev. Chem. Biomol. Eng. 2015, 6, 319-345. [CrossRef]

57. Bolivar, J.M.; López-Gallego, F. Characterization and evaluation of immobilized enzymes for applications in flow reactors. Curr. Opin. Green Sustain. Chem. 2020, 25, 100349. [CrossRef]

58. Woodley, J.M. New frontiers in biocatalysis for sustainable synthesis. Curr. Opin. Green Sustain. Chem. 2020, 21, 22-26. [CrossRef]

59. Sheldon, R.A.; van Pelt, S. Enzyme immobilisation in biocatalysis: Why, what and how. Chem. Soc. Rev. 2013, 42, 6223-6235. [CrossRef]

60. Boudrant, J.; Woodley, J.M.; Fernandez-Lafuente, R. Parameters necessary to define an immobilized enzyme preparation. Process. Biochem. 2020, 90, 66-80. [CrossRef]

61. Singhania, R.R.; Patel, A.K.; Pandey, A. The Industrial Production of Enzymes. In Industrial Biotechnology; Soetaert, W., Vandamme, E.J., Eds.; Wiley-VCH Verlag GmbH \& Co.: Weinheim, Germany, 2021; pp. 207-225.

62. Agyei, D.; Shanbhag, B.K.; He, L. Enzyme engineering (immobilization) for food applications. In Improving and Tailoring Enzymes for Food Quality and Functionality; Yada, R.Y., Ed.; Elsevier: Amsterdam, The Netherlands, 2015; pp. $213-236$.

63. Brena, B.; González-Pombo, P.; Batista-Viera, F. Immobilization of enzymes: A literature survey. Methods Mol. Biol. 2009, 1051, 15-31.

64. Jesionowski, T.; Zdarta, J.; Krajewska, B. Enzyme immobilization by adsorption: A review. Adsorption 2014, 20, 801-821. [CrossRef]

65. Gonçalves, M.; Amaral, J.C.; Lopes, L.A.; Fernandez-Lafuente, R.; Tardioli, P.W. Stabilization and operational selectivity alteration of Lipozyme 435 by its coating with polyethyleneimine: Comparison of the biocatalyst performance in the synthesis of xylose fatty esters. Int. J. Biol. Macromol. 2021, 192, 665-674. [CrossRef]

66. Rueda, N.; Santos, C.S.D.; Rodriguez, M.D.; Albuquerque, T.L.; Barbosa, O.; Torres, R.; Ortiz, C.; Fernandez-Lafuente, R. Reversible immobilization of lipases on octyl-glutamic agarose beads: A mixed adsorption that reinforces enzyme immobilization. J. Mol. Catal. B Enzym. 2016, 128, 10-18. [CrossRef]

67. Sheldon, R.A.; Basso, A.; Brady, D. New frontiers in enzyme immobilisation: Robust biocatalysts for a circular bio-based economy. Chem. Soc. Rev. 2021, 50, 5850-5862. [CrossRef]

68. Zhou, L.J.; Li, R.F.; Li, X.Y.; Zhang, Y.W. One-step selective affinity purification and immobilization of His-tagged enzyme by recyclable magnetic nanoparticles. Eng. Life Sci. 2021, 21, 364-373. [CrossRef]

69. Zhou, J.; Chen, J.; Zhuang, N.; Zhang, A.; Chen, K.; Xu, N.; Xin, F.; Zhang, W.; Dong, W.; Jiang, M. Immobilization and Purification of Enzymes with the Novel Affinity Tag ChBD-AB from Chitinolyticbacter meiyuanensis SYBC-H1. Front. Bioeng. Biotechnol. 2020, 8 , 579. [CrossRef]

70. Wahab, R.A.; Elias, N.; Abdullah, F.; Ghoshal, S.K. On the taught new tricks of enzymes immobilization: An all-inclusive overview. React. Funct. Polym. 2020, 152, 104613. [CrossRef]

71. Fernández-Lorente, G.; Lopez-Gallego, F.; Bolivar, J.M.; Rocha-Martin, J.; Moreno-Perez, S.; Guisán, J.M. Immobilization of proteins on highly activated glyoxyl supports: Dramatic increase of the enzyme stability via multipoint immobilization on pre-existing carriers. Curr. Org. Chem. 2015, 19, 1719-1731. [CrossRef]

72. Weltz, J.S.; Kienle, D.F.; Schwart, D.K.; Kaar, J.L. Reduced Enzyme Dynamics upon Multipoint Covalent Immobilization Leads to Stability-Activity Trade-off. J. Am. Chem. Soc. 2020, 142, 3463-3471. [CrossRef] [PubMed]

73. Novick, S.J.; Rozzell, J.D. Immobilization of Enzymes by Covalent Attachment. In Microbial Enzymes and Biotransformations. Methods in Biotechnology; Barredo, J.L., Ed.; Humana Press: Totowa, NJ, USA, 2005; Volume 17, pp. $247-271$.

74. Orrego, H.A.; Romero-Fernández, M.; Millán-Linares, M.C.; Pedroche, J.; Guisán, J.M.; Rocha-Martin, J. High Stabilization of Enzymes Immobilized on Rigid Hydrophobic Glyoxyl-Supports: Generation of Hydrophilic Environments on Support Surfaces. Catalysts 2020, 10, 676. [CrossRef] 
75. Bolivar, J.M.; Rocha-Martin, J.; Mateo, C.; Cava, F.; Berenguer, J.; Fernandez-Lafuente, R.; Guisan, J.M. Coating of soluble and immobilized enzymes with ionic polymers: Full stabilization of the quaternary structure of multimeric enzymes. Biomacromolecules 2009, 10, 742-747. [CrossRef] [PubMed]

76. Roura Padrosa, D.; Benítez-Mateos, A.I.; Calvey, L.; Paradisi, F. Cell-free biocatalytic syntheses of l-pipecolic acid: A dual strategy approach and process intensification in flow. Green Chem. 2020, 22, 5310-5316. [CrossRef]

77. Ovsejevi, K.; Manta, C.; Batista-Viera, F. Reversible covalent immobilization of enzymes via disulfide bonds. Methods Mol. Biol. 2013, 1051, 89-116. [PubMed]

78. Guzik, U.; Hupert-Kocurek, K.; Marchlewicz, A.; Wojcieszyńska, D. Enhancement of biodegradation potential of catechol 1,2-dioxygenase through its immobilization in calcium alginate gel. Electron. J. Biotechnol. 2014, 17, 83-88. [CrossRef]

79. Schmieg, B.; Schimek, A.; Franzreb, M. Development and performance of a 3D-printable poly(ethylene glycol) diacrylate hydrogel suitable for enzyme entrapment and long-term biocatalytic applications. Eng. Life Sci. 2018, 18, 659-667. [CrossRef]

80. Meyer, J.; Meyer, L.-E.; Kara, S. Enzyme immobilization in hydrogels: A perfect liaison for efficient and sustainable biocatalysis. Eng. Life. Sci. 2021, in press. [CrossRef]

81. Cao, L.; van Langen, L.; Sheldon, R.A. Immobilised enzymes: Carrier-bound or carrier-free? Curr. Opin. Biotechnol. 2003, 14, 387-394. [CrossRef]

82. Xu, D.Y.; Yang, Z. Cross-linked tyrosinase aggregates for elimination of phenolic compounds from wastewater. Chemosphere 2013, 92, 391-398. [CrossRef] [PubMed]

83. Minteer, S.D. Cell-free biotechnologies. In Biotechnology for Biofuel Production and Optimization; Eckert, C.A., Trinh, C.T., Eds.; Elsevier: Amsterdam, The Netherlands, 2016; pp. 433-448.

84. Husain, Q.; Ansari, S.A.; Alam, F.; Azam, A. Immobilization of Aspergillus oryzae $\beta$ galactosidase on zinc oxide nanoparticles via simple adsorption mechanism. Int. J. Biol. Macromol. 2011, 49, 37-43. [CrossRef]

85. Karakuş, E.; Pekyardımcı, S. Comparison of Covalent and Noncovalent Immobilization of Malatya Apricot Pectinesterase (Prunus armeniaca L.). Artif. Cells Blood Substit. Immobil. Biotechnol. 2012, 40, 132-141. [CrossRef] [PubMed]

86. Siqueira, N.M.; Garcia, K.C.; Bussamara, R.; Both, F.S.; Vainstein, M.H.; Soares, R.M.D. Poly (lactic acid)/chitosan fiber mats: Investigation of effects of the support on lipase immobilization. Int. J. Biol. Macromol. 2015, 72, 998-1004. [CrossRef]

87. Lee, C.H.; Jin, E.S.; Lee, J.H.; Hwang, E.T. Immobilization and Stabilization of Enzyme in Biomineralized Calcium Carbonate Microspheres. Front. Bioeng. Biotechnol. 2020, 8, 553591. [CrossRef]

88. Arıca, M.Y.; Bayramoğlu, G. Invertase reversibly immobilized onto polyethylenimine-grafted poly(GMA-MMA) beads for sucrose hydrolysis. J. Mol. Catal. B Enzym. 2006, 38, 131-138. [CrossRef]

89. Cabral, B.V.; Santos, L.D.; Larissa, N.S.; Falleiros, S.; Taciana, S.C.; Freitas, F.F.; Cardoso, S.L. Sucrose hydrolysis by invertase immobilized on Duolite A-568 employing a packed-bed reactor. Chem. Eng. Commun. 2017, 204, 1007-1019. [CrossRef]

90. Morshed, M.N.; Behary, N.; Guan, J.P.; Nierstrasz, V.A. Immobilizing redox enzyme on amino functional group-integrated tailor-made polyester textile: High loading, stability, and application in a bio-fenton system. ACS Sustain. Chem. Eng. 2021, 9 , 8879-8894. [CrossRef]

91. Dal Magro, L.; Kornecki, J.F.; Klein, M.P.; Rodrigues, R.C.; Fernandez-Lafuente, R. Optimized immobilization of polygalacturonase from Aspergillus niger following different protocols: Improved stability and activity under drastic conditions. Int. J. Biol. Macromol. 2019, 138, 234-243. [CrossRef] [PubMed]

92. Hassan, M.E.; Yang, Q.; Xiao, Z. Covalent immobilization of glucoamylase enzyme onto chemically activated surface of $\mathrm{k}$ carrageenan. Bull. Natl. Res. Cent. 2019, 43, 102. [CrossRef]

93. Alagöz, D.; Toprak, A.; Yildirim, D.; Tükel, S.S.; Fernandez-Lafuente, R. Modified silicates and carbon nanotubes for immobilization of lipase from Rhizomucor miehei: Effect of support and immobilization technique on the catalytic performance of the immobilized biocatalysts. Enzym. Microb. Technol. 2021, 144, 109739. [CrossRef] [PubMed]

94. Alagöz, D.; Varan, N.E.; Toprak, A.; Yildirim, D.; Tukel, S.S.; Fernandez-Lafuente, R. Immobilization of xylanase on differently functionalized silica gel supports for orange juice clarification. Process. Biochem. 2022, 113, 270-280. [CrossRef]

95. Nawaz, M.A.; Rehman, H.U.; Bibi, Z.; Aman, A.; Ul Qader, S.A. Continuous degradation of maltose by enzyme entrapment technology using calcium alginate beads as a matrix. Biochem. Biophys. Rep. 2015, 4, 250-256. [CrossRef] [PubMed]

96. Raghu, S.; Pennathur, G. Enhancing the stability of a carboxylesterase by entrapment in chitosan coated alginate beads. Turk. J. Biol. 2018, 42, 307-318. [CrossRef] [PubMed]

97. Qi, D.; Gao, M.; Li, X.; Lin, J. Immobilization of Pectinase onto Porous Hydroxyapatite/Calcium Alginate Composite Beads for Improved Performance of Recycle. ACS Omega 2020, 5, 20062-20069. [CrossRef] [PubMed]

98. Suvarli, N.; Wenger, L.; Serra, C.; Perner-Nochta, I.; Hubbuch, J.; Wörner, M. Immobilization of $\beta$-Galactosidase by Encapsulation of Enzyme-Conjugated Polymer Nanoparticles Inside Hydrogel Microparticles. Front. Bioeng. Biotechnol. $2022,9,818053$. [CrossRef]

99. Rasbold, L.M.; Delai, V.M.; da Cruz Kerber, C.M.; Simões, M.R.; Heinen, P.R.; da Conceição Silva, J.L.; Simão, R.C.G.; Kadowaki, M.K.; Maller, A. Production, immobilization and application of invertase from new wild strain Cunninghamella echinulata PA3S12MM. J. Appl. Microbiol. 2021, in press. [CrossRef] [PubMed]

100. van Pelt, S.; Quignard, S.; Kubac, D.; Dimitry, Y.S.B.; van Rantwijk, F.; Sheldon, R.A. Nitrile hydratase CLEAs: The immobilization and stabilization of an industrially important enzyme. Green Chem. 2008, 10, 395-400. [CrossRef] 
101. Nadar, S.S.; Muley, A.B.; Ladole, M.R.; Joshi, P.U. Macromolecular cross-linked enzyme aggregates (M-CLEAs) of $\alpha$-amylase. Int. J. Biol. Macromol. 2016, 84, 69-78. [CrossRef] [PubMed]

102. Rehman, S.; Bhatti, H.N.; Bilal, M.; Asgher, M. Cross-linked enzyme aggregates (CLEAs) of Pencilluim notatum lipase enzyme with improved activity, stability and reusability characteristics. Int. J. Biol. Macromol. 2016, 91, 1161-1169. [CrossRef] [PubMed]

103. Zang, Y.Y.; Yang, S.; Xu, Y.Q.; Chen, Z.G.; Wu, T. Carrier-Free Immobilization of Rutin Degrading Enzyme Extracted From Fusarium spp. Front. Bioeng. Biotechnol. 2020, 8, 470. [CrossRef] [PubMed]

104. Yan, H.; Shi, B.; Ding, J.; Zhu, H.; Li, X.; Qian, J. Preparation and characterization of a nontoxic cross-linked lipase aggregate by using sodium tripolyphosphate and chitosan. J. Appl. Polym. Sci. 2022, 139, e51871. [CrossRef]

105. Doraiswamy, N.; Sarathi, M.; Pennathur, G. Cross-linked esterase aggregates (CLEAs) using nanoparticles as immobilization matrix. Prep. Biochem. Biotechnol. 2019, 49, 270-278. [CrossRef] [PubMed]

106. Paitaid, P.; H-Kittikun, A. Magnetic Cross-Linked Enzyme Aggregates of Aspergillus oryzae ST11 Lipase Using Polyacrylonitrile Coated Magnetic Nanoparticles for Biodiesel Production. Appl. Biochem. Biotechnol. 2020, 190, 1319-1332. [CrossRef] [PubMed]

107. Lucena, G.N.; dos Santos, C.C.; Pinto, G.C.; Piazza, R.D.; Guedes, W.N.; Jafelicci Junior, M.; de Paula, A.V.; Marques, R.F.C. Synthesis and characterization of magnetic cross-linked enzyme aggregate and its evaluation of the alternating magnetic field (AMF) effects in the catalytic activity. J. Magn. Magn. Mater. 2020, 516, 167326. [CrossRef]

108. Wei, B.; Liu, F.; Liu, X.; Cheng, L.; Yuan, O.; Gao, H.; Liang, H. Enhancing stability and by-product tolerance of $\beta$-glucuronidase based on magnetic cross-linked enzyme aggregates. COLSUB 2022, 210, 112241. [CrossRef]

109. Faccio, G. From Protein Features to Sensing Surfaces. Sensors 2018, 18, 1204. [CrossRef] [PubMed]

110. Benítez-Mateos, A.I.; Contente, M.L. Agarose vs. Methacrylate as Material Supports for Enzyme Immobilization and Continuous Processing. Catalysts 2021, 11, 814. [CrossRef]

111. Engelmann, C.; Ekambaram, N.; Johannsen, J.; Fellechner, O.; Waluga, T.; Fieg, G.; Liese, A.; Bubenheim, P. Enzyme Immobilization on Synthesized Nanoporous Silica Particles and their Application in a Bi-enzymatic Reaction. ChemCatChem 2020, 12, $2245-2252$. [CrossRef]

112. Kahar, U.M.; Sani, M.H.; Chan, K.-G.; Goh, K.M. Immobilization of $\alpha$-Amylase from Anoxybacillus sp. SK3-4 on ReliZyme and Immobead Supports. Molecules 2016, 21, 1196. [CrossRef]

113. Dinu, C.Z.; Zhu, G.; Bale, S.S.; Anand, G.; Reeder, P.J.; Sanford, K.; Whited, G.; Kane, R.S.; Dordick, J.S. Enzyme-based nanoscale composites for use as active decontamination surfaces. Adv. Funct. Mater. 2010, 20, 392-398. [CrossRef]

114. Moskovitz, Y.; Srebnik, S. Conformational changes of globular proteins upon adsorption on a hydrophobic surface. Phys. Chem. Chem. Phys. 2014, 16, 11698-11707. [CrossRef] [PubMed]

115. Anand, G.; Sharma, S.; Dutta, A.K.; Kumar, S.K.; Belfort, G. Conformational Transitions of Adsorbed Proteins on Surfaces of Varying Polarity. Langmuir 2010, 26, 10803-10811. [CrossRef] [PubMed]

116. Sethuraman, A.; Vedantham, G.; Imoto, T.; Przybycien, T.; Belfort, G. Protein Unfolding at Interfaces: Slow Dynamics of $\alpha$-Helix to $\beta$-Sheet Transition. Proteins 2004, 56, 669-678. [CrossRef] [PubMed]

117. Jin, Q.; Jia, G.; Zhang, Y.; Yang, Q.; Li, C. Hydrophobic Surface Induced Activation of Pseudomonas Cepacia Lipase Immobilized into Mesoporous Silica. Langmuir 2011, 27, 12016-12024. [CrossRef] [PubMed]

118. Fernandez-Lopez, L.; Rueda, N.; Bartolome-Cabrero, R.; Rodriguez, M.D.; Albuquerque, T.L.; Dos Santos, J.C.S.; Barbosa, O.; Fernandez-Lafuente, R. Improved immobilization and stabilization of lipase from Rhizomucor miehei on octyl-glyoxyl agarose beads by using $\mathrm{CaCl}_{2}$. Process. Biochem. 2016, 51, 48-52. [CrossRef]

119. Rodrigues, R.C.; Virgen-Ortíz, J.J.; dos Santos, J.C.S.; Berenguer-Murcia, Á.; Alcantara, A.R.; Barbosa, O.; Ortiz, C.; Fernandez-Lafuente, R. Immobilization of lipases on hydrophobic supports: Immobilization mechanism, advantages, problems, and solutions. Biotechnol. Adv. 2019, 37, 746-770. [CrossRef]

120. Benítez-Mateos, A.I.; Huber, C.; Nidetzky, B.; Bolivar, J.M.; López-Gallego, F. Design of the Enzyme-Carrier Interface to Overcome the $\mathrm{O}_{2}$ and NADH Mass Transfer Limitations of an Immobilized Flavin Oxidase. ACS Appl. Mater. Interfaces 2020, 12, 56027-56038. [CrossRef]

121. Grimaldi, J.; Radhakrishna, M.; Kumar, S.K.; Belfort, G. Stability of proteins on hydrophilic surfaces. Langmuir 2015, 31, 1005-1010. [CrossRef] [PubMed]

122. Bayne, L.; Ulijn, R.V.; Halling, P.J. Effect of pore size on the performance of immobilised enzymes. Chem. Soc. Rev. 2013, 42, 9000-9010. [CrossRef] [PubMed]

123. Chen, B.; Qiu, J.; Mo, H.; Yu, Y.; Ito, K.; Sakai, E.; Feng, H. Synthesis of mesoporous silica with different pore sizes for cellulase immobilization: Pure physical adsorption. New J. Chem. 2017, 41, 9338-9345. [CrossRef]

124. Takimoto, A.; Shiomi, T.; Ino, K.; Tsunoda, T.; Kawai, A.; Mizukami, F.; Sakaguchi, K. Encapsulation of Cellulase with Mesoporous Silica (SBA-15). Microporous Mesoporous Mater. 2008, 116, 601-606. [CrossRef]

125. Kuo, P.-C.; Lin, Z.-X.; Wu, T.-Y.; Hsu, C.-H.; Lin, H.-P.; Wu, T.-S. Effects of morphology and pore size of mesoporous silicas on the efficiency of an immobilized enzyme. RSC Adv. 2021, 11, 10010-10017. [CrossRef]

126. Caldas, E.M.; Novatzky, D.; Deon, M.; de Menezes, E.W.; Hertz, P.F.; Costa, T.M.H.; Arenas, L.T.; Benvenutti, E.V. Pore size effect in the amount of immobilized enzyme for manufacturing carbon ceramic biosensor. Microporous Mesoporous Mater. 2017, 247, 95-102. [CrossRef]

127. Califano, V.; Costantini, A.; Silvestri, B.; Venezia, V.; Cimino, S.; Sannino, F. The effect of pore morphology on the catalytic performance of $\beta$-glucosidase immobilized into mesoporous silica. Pure Appl. Chem. 2019, 91, 1583-1592. [CrossRef] 
128. Tadepalli, S.; Wang, Z.; Slocik, J.; Naik, R.R.; Singamaneni, S. Effect of size and curvature on the enzyme activity of bionanoconjugates. Nanoscale 2017, 9, 15666-15672. [CrossRef]

129. Peng, G.; Hou, X.; Liu, B.; Chen, H.; Luo, R. Stabilized enzyme immobilization on micron-size PSt-GMA microspheres: Different methods to improve the carriers' surface biocompatibility. RSC Adv. 2016, 6, 91431-91439. [CrossRef]

130. Shinde, P.; Musameh, M.; Gao, Y.; Robinson, A.J.; Kyratzis, I. Immobilization and stabilization of alcohol dehydrogenase on polyvinyl alcohol fibre. Biotechnol. Rep. 2018, 19, e00260. [CrossRef] [PubMed]

131. Abaházi, E.; Lestál, D.; Boros, Z.; Poppe, L. Tailoring the Spacer Arm for Covalent Immobilization of Candida antarctica Lipase B-Thermal Stabilization by Bisepoxide-Activated Aminoalkyl Resins in Continuous-Flow Reactors. Molecules 2016, $21,767$. [CrossRef] [PubMed]

132. Contente, M.L.; Farris, S.; Tamborini, L.; Molinari, F.; Paradisi, F. Flow-Based Enzymatic Synthesis of Melatonin and Other High Value Tryptamine Derivatives: A Five-Minute Intensified Process. Green Chem. 2019, 21, 3263-3266. [CrossRef]

133. Romero, O.; Guisán, J.M.; Illanes, A.; Wilson, L. Reactivation of penicillin acylase biocatalysts: Effect of the intensity of enzymesupport attachment and enzyme load. J. Mol. Catal. B Enzym. 2012, 74, 224-229. [CrossRef]

134. Arana-Peña, S.; Rios, N.S.; Carballares, D.; Mendez-Sanchez, C.; Lokha, Y.; Gonçalves, L.R.B.; Fernandez-Lafuente, R. Effects of Enzyme Loading and Immobilization Conditions on the Catalytic Features of Lipase From Pseudomonas fluorescens Immobilized on Octyl-Agarose Beads. Front. Bioeng. Biotechnol. 2020, 8, 36. [CrossRef]

135. .García-García, P.; Fernandez-Lorente, G.; Guisan, J.M. Capture of enzyme aggregates by covalent immobilization on solid supports. Relevant stabilization of enzymes by aggregation. J. Biotechnol. 2021, 325, 138-144. [CrossRef]

136. Li, Y.-M.; Yuan, J.; Ren, H.; Ji, C.-Y.; Tao, Y.; Wu, Y.; Chou, L.-Y.; Zhang, Y.-B.; Cheng, L. Fine-Tuning the Micro-Environment to Optimize the Catalytic Activity of Enzymes Immobilized in Multivariate Metal-Organic Frameworks. J. Am. Chem. Soc. 2021, 143, 15378-15390. [CrossRef]

137. Ruiz, M.; Plata, E.; Castillo, J.J.; Ortiz, C.C.; López, G.; Baena, S.; Torre, R.; Fernandez-Lafuente, R. Modulation of the Biocatalytic Properties of a Novel Lipase from Psychrophilic Serratia sp. (USBA-GBX-513) by Different Immobilization Strategies. Molecules 2021, 26, 1574. [CrossRef]

138. Fernandez-Lafuente, R. Stabilization of multimeric enzymes: Strategies to prevent subunit dissociation. Enzym. Microb. Technol. 2009, 45, 405-418. [CrossRef]

139. García-García, P.; Guisan, J.M.; Fernandez-Lorente, G.A. Mild intensity of the enzyme-support multi-point attachment promotes the optimal stabilization of mesophilic multimeric enzymes: Amine oxidase from Pisum sativum. J. Biotechnol. 2020, 318, 39-44. [CrossRef]

140. Zhu, L.; Wang, S.; Tian, W.; Zhang, Y.; Song, Y.; Zhang, J.; Mu, B.; Peng, C.; Deng, Z.; Ma, H.; et al. Stabilization of multimeric proteins via intersubunit cyclization. Appl. Environ. Microbiol. 2017, 83, e01239-17. [CrossRef] [PubMed]

141. Tao, Q.; Li, A.; Zhang, Z.; Ma, R.; Shi, L. Stabilization of multimeric enzymes against heat inactivation by chitosan-graft-poly(Nisopropylacrylamide) in confined spaces. ACS Biomater. Sci. Eng. 2017, 3, 3141-3145. [CrossRef] [PubMed]

142. Trobo-Maseda, L.; Orrego, A.H.; Moreno-Pérez, S.; Fernández-Lorente, G.; Guisan, J.M.; Rocha-Martin, J. Stabilization of multimeric sucrose synthase from Acidithiobacillus caldus via immobilization and post-immobilization techniques for synthesis of UDP-glucose. Appl. Microbiol. Biotechnol. 2018, 102, 773-787. [CrossRef] [PubMed]

143. Mateo, C.; Pessela, B.; Fuentes, M.; Torres, R.; Betancor, L.; Hidalgo, A.; Fernandez-Lorente, G.; Fernandez-Lafuente, R.; Guisan, J.M. Stabilization of Multimeric Enzymes via Immobilization and Further Cross-Linking with Aldehyde-Dextran. In Immobilization of Enzymes and Cells. Methods in Molecular Biology; Guisan, J., Bolivar, J., López-Gallego, F., Rocha-Martín, J., Eds.; Humana: New York, NY, USA, 2020; Volume 2100, pp. 175-187.

144. Rodrigues, R.C.; Berenguer-Murcia, Á.; Carballares, D.; Morellon-Sterling, R.; Fernandez-Lafuente, R. Stabilization of enzymes via immobilization: Multipoint covalent attachment and other stabilization strategies. Biotechnol. Adv. 2021, 52, 107821. [CrossRef] [PubMed]

145. Cavalcante, F.T.T.; Cavalcante, A.L.G.; de Sousa, I.G.; Neto, F.S.; dos Santos, J.C.S. Current Status and Future Perspectives of Supports and Protocols for Enzyme Immobilization. Catalysts 2021, 11, 1222. [CrossRef]

146. Liu, X.; Formanek, P.; Voit, B.; Appelhans, D. Functional Cellular Mimics for the Spatiotemporal Control of Multiple Enzymatic Cascade Reactions. Angew. Chem. Int. Ed. Engl. 2017, 56, 16233-16238. [CrossRef]

147. Bernal, C.; Rodríguez, K.; Martínez, R. Integrating enzyme immobilization and protein engineering: An alternative path for the development of novel and improved industrial biocatalysts. Biotechnol. Adv. 2018, 36, 1470-1480. [CrossRef]

148. Zdarta, J.; Meyer, A.S.; Jesionowski, T.; Pinelo, M.A. General Overview of Support Materials for Enzyme Immobilization: Characteristics, Properties, Practical Utility. Catalysts 2018, 8, 92. [CrossRef]

149. Cen, Y.-K.; Liu, Y.-X.; Xue, Y.-P.; Zheng, Y.-G. Immobilization of Enzymes in/on Membranes and their Applications. Adv. Synth. Catal. 2019, 361, 5500-5515. [CrossRef]

150. Bilal, M.; Asgher, M.; Cheng, H.; Yan, Y.; Iqbal, H.M.N. Multi-point enzyme immobilization, surface chemistry, and novel platforms: A paradigm shift in biocatalyst design. Crit Rev. Biotechnol. 2019, 39, 202-219. [CrossRef]

151. Ye, N.; Kou, X.; Shen, J.; Huang, S.; Chen, G.; Ouyang, G. Metal-Organic Frameworks: A New Platform for Enzyme Immobilization. ChemBioChem 2020, 21, 2585-2590. [CrossRef] [PubMed]

152. Aggarwal, S.; Chakravarty, A.; Ikram, S. A comprehensive review on incredible renewable carriers as promising platforms for enzyme immobilization \& thereof strategies. Int. J. Biol. Macromol. 2021, 167, 962-986. [PubMed] 
153. Ding, S.S.; Zhu, J.P.; Wang, Y.; Yu, Y.; Zhao, Z. Recent progress in magnetic nanoparticles and mesoporous materials for enzyme immobilization: An update. Braz. J. Biol. 2021, 82, e244496. [CrossRef]

154. Liu, D.M.; Chen, J.; Shi, Y.P. Advances on methods and easy separated support materials for enzymes immobilization. Trends Analyt. Chem. 2018, 102, 332-342. [CrossRef]

155. Rodríguez-Núñez, K.; Berna, C.; Martínez, R. Immobilized Biocatalyst Engineering: High throughput enzyme immobilization for the integration of biocatalyst improvement strategies. Biotechnol. Adv. 2021, 36, 1470-1480. [CrossRef] [PubMed]

156. Gkantzou, E.; Chatzikonstantinou, A.V.; Fotiadou, R.; Giannakopoulou, A.; Patila, M.; Stamatis, H. Trends in the development of innovative nanobiocatalysts and their application in biocatalytic transformations. Biotechnol. Adv. 2021, 51, 107738. [CrossRef] [PubMed]

157. Betancor, L.; Luckarift, H. Co-immobilized coupled enzyme systems in biotechnology. Biotechnol. Genet. Eng. Rev. 2010, 27, 95-114. [CrossRef]

158. Gruber, P.; Marques, M.P.C.; O'Sullivan, B.; Baganz, F.; Wohlgemuth, R.; Szita, N. Conscious coupling: The challenges and opportunities of cascading enzymatic microreactors. Biotechnol. J. 2017, 12, 1700030. [CrossRef]

159. Jiang, Y.; Li, Z.; Zheng, S.; Xu, H.; Zhou, Y.J.; Gao, Z.; Meng, C.; Li, S. Establishing an enzyme cascade for one-pot production of $\alpha$-olefins from low-cost triglycerides and oils without exogenous $\mathrm{H}_{2} \mathrm{O}_{2}$ addition. Biotechnol. Biofuels 2020, 13, 52. [CrossRef]

160. Metzner, R.; Hummel, W.; Wetterich, F.; König, B.; Gröger, H. Integrated biocatalysis in multistep drug synthesis without intermediate isolation: A de novo approach toward a rosuvastatin key building block. Org. Process. Res. Dev. 2015, 19, 635-638. [CrossRef]

161. Rudroff, F.; Mihovilovic, M.D.; Gröger, H.; Snajdrova, R.; Iding, H.; Bornscheuer, U.T. Opportunities and challenges for combining chemo- and biocatalysis. Nat. Catal. 2018, 1, 12-22. [CrossRef]

162. Mestrom, L.; Przypis, M.; Kowalczykiewicz, D.; Pollender, A.; Kumpf, A.; Marsden, S.R.; Bento, I.; Jarzębski, A.B.; Szymańska, K.; Chruściel, A.; et al. Leloir Glycosyltransferases in Applied Biocatalysis: A Multidisciplinary Approach. Int. J. Mol. Sci. 2019, 20, 5263. [CrossRef]

163. Li, Y.; Wen, L.; Tan, T.; Lv, Y. Sequential Co-immobilization of Enzymes in Metal-Organic Frameworks for Efficient Biocatalytic Conversion of Adsorbed $\mathrm{CO}_{2}$ to Formate. Front. Bioeng. Biotechnol. 2019, 7, 394. [CrossRef] [PubMed]

164. Arana-Peña, S.; Carballares, D.; Morellon-Sterlling, R.; Berenguer-Murcia, Á.; Alcántara, A.R.; Rodrigues, R.C.; FernandezLafuente, R. Enzyme co-immobilization: Always the biocatalyst designers' choice ... or not? Biotechnol. Adv. 2020, $51,107584$. [CrossRef] [PubMed]

165. Ricca, E.; Brucher, B.; Schrittwieser, J.H. Multi-enzymatic cascade reactions: Overview and perspectives. Adv. Synth. Catal. 2011, 353, 2239-2262. [CrossRef]

166. Muschiol, J.; Peters, C.; Oberleitner, N.; Mihovilovic, M.D.; Bornscheuer, U.T.; Rudroff, F. Cascade catalysis—Strategies and challenges en route to preparative synthetic biology. Chem. Commun. 2015, 51, 5798-5811. [CrossRef]

167. Robescu, M.S.; Serra, I.; Terreni, M.; Ubiali, D.; Bavaro, T. A Multi-Enzymatic Cascade Reaction for the Synthesis of Vidarabine 5'-Monophosphate. Catalysts 2020, 10, 60. [CrossRef]

168. Velasco-Lozano, S.; Santiago-Arcos, J.; Mayoral, J.A.; López-Gallego, F. Co-immobilization and colocalization of multi-enzyme systems for the cell-free biosynthesis of aminoalcohols. ChemCatChem 2020, 12, 3030-3041. [CrossRef]

169. Kazenwadel, F.; Franzreb, M.; Rapp, B.E. Synthetic enzyme supercomplexes: Co-immobilization of enzyme cascades. Anal. Methods 2015, 7, 4030-4037. [CrossRef]

170. Quin, M.B.; Wallin, K.K.; Zhang, G.; Schmidt-Dannert, C. Spatial organization of multi-enzyme biocatalytic cascades. Org. Biomol. Chem. 2017, 15, 4260-4271. [CrossRef] [PubMed]

171. Hwang, E.T.; Lee, S. Multienzymatic cascade reactions via enzyme complex by immobilization. ACS Catal. $2019,9,4402-4425$. [CrossRef]

172. Giannakopoulou, A.; Gkantzou, E.; Polydera, A.; Stamatis, H. Multienzymatic Nanoassemblies: Recent Progress and Applications. Trends Biotechnol. 2020, 38, 202-216. [CrossRef]

173. Xu, K.; Chen, X.; Zheng, R.; Zheng, Y. Immobilization of Multi-Enzymes on Support Materials for Efficient Biocatalysis. Front. Bioeng. Biotechnol. 2020, 8, 660. [CrossRef] [PubMed]

174. Júnior, A.A.D.T.; Ladeira, Y.F.X.; França, A.D.S.; Souza, R.O.M.A.D.; Moraes, A.H.; Wojcieszak, R.; Itabaiana, I., Jr.; Miranda, A.S.D. Multicatalytic Hybrid Materials for Biocatalytic and Chemoenzymatic Cascades-Strategies for Multicatalyst (Enzyme) Co-Immobilization. Catalysts 2021, 11, 936. [CrossRef]

175. Cutlan, R.; De Rose, S.; Isupov, M.N.; Littlechild, J.A.; Harmer, N.J. Using enzyme cascades in biocatalysis: Highlight on transaminases and carboxylic acid reductases. Biochim. Biophys. Acta Proteins Proteom. 2020, 1868, 140322. [CrossRef]

176. McIntosh, J.A.; Owens, A. Enzyme engineering for biosynthetic cascades. Curr. Opin. Green Sustain. Chem. 2021, 29, 100448. [CrossRef]

177. Schwizer, F.; Okamoto, Y.; Heinisch, T.; Gu, Y.; Pellizzoni, M.M.; Lebrun, V.; Reuter, R.; Köhler, V.; Lewis, J.C.; Ward, T.R. Artificial Metalloenzymes: Reaction Scope and Optimization Strategies. Chem. Rev. 2018, 118, 142-231. [CrossRef] [PubMed]

178. Palomo, J.M. Artificial enzymes with multiple active sites. Curr. Opin. Green Sustain. Chem. 2021, 29, 100452. [CrossRef]

179. Küchler, A.; Yoshimoto, M.; Luginbühl, S.; Mavelli, F.; Walde, P. Enzymatic reactions in confined environments. Nat. Nanotech. 2016, 11, 409-420. [CrossRef] 
180. Shi, J.; Wu, Y.; Zhang, S.; Tian, Y.; Yang, D.; Jiang, Z. Bioinspired construction of multi-enzyme catalytic systems. Chem. Soc. Rev. 2018, 47, 4295-4313. [CrossRef]

181. Lechner, H.; Ferruz, N.; Höcker, B. Strategies for designing non-natural enzymes and binders. Curr. Opin. Chem. Biol. 2018, 47, 67-76. [CrossRef] [PubMed]

182. Li, X.; Cao, Y.; Luo, K.; Sun, Y.Z.; Xiong, J.R.; Wang, L.C.; Liu, Z.; Li, J.; Ma, J.Y.; Ge, J.; et al. Highly active enzyme-metal nanohybrids synthesized in protein-polymer conjugates. Nat. Catal. 2019, 2, 718-725. [CrossRef]

183. Ren, S.; Wang, Z.; Bilal, M.; Feng, Y.; Jiang, Y.; Jia, S.; Cui, J. Co-immobilization multienzyme nanoreactor with co-factor regeneration for conversion of $\mathrm{CO}_{2}$. Int. J. Biol. Macromol. 2020, 155, 110-118. [CrossRef] [PubMed]

184. Orrego, A.H.; López-Gallego, F.; Fernandez-Lorente, G.; Guisan, J.M.; Rocha-Martín, J. Co-Immobilization and Co-Localization of Multi-Enzyme Systems on Porous Materials. In Immobilization of Enzymes and Cells. Methods in Molecular Biology; Guisan, J., Bolivar, J., López-Gallego, F., Rocha-Martín, J., Eds.; Humana: New York, NY, USA, 2020; Volume 2100, pp. $297-308$.

185. Schoffelen, S.; van Hest, J.C. Chemical approaches for the construction of multi-enzyme reaction systems. Curr. Opin. Struct. Biol. 2013, 23, 613-621. [CrossRef]

186. Chen, Q.; Liu, D.; Wu, C.; Yao, K.; Li, Z.; Shi, N.; Wen, F.; Gates, I.D. Co-immobilization of cellulase and lysozyme on aminofunctionalized magnetic nanoparticles: An activity-tunable biocatalyst for extraction of lipids from microalgae. Bioresour. Technol. 2018, 263, 317-324. [CrossRef]

187. Vong, T.; Schoffelen, S.; van Dongen, S.F.M.; van Beek, T.A.; Zuilhof, H.; van Hest, J.C.M. A DNA-Based Strategy for Dynamic Positional Enzyme Immobilization Inside Fused Silica Microchannels. Chem. Sci. 2011, 2, 1278-1285. [CrossRef]

188. Boehm, C.R.; Freemont, P.S.; Ces, O. Design of a prototype flow microreactor for synthetic biology in vitro. Lab Chip 2013, 13, 3426-3432. [CrossRef]

189. Chen, Y.; Ke, G.; Ma, Y.; Zhu, Z.; Liu, M.; Liu, Y.; Yan, H.; Yang, C.J. A Synthetic Light-Driven Substrate Channeling System for Precise Regulation of Enzyme Cascade Activity Based on DNA Origami. J. Am. Chem. Soc. 2018, 140, 8990-8996. [CrossRef] [PubMed]

190. Klein, W.P.; Thomsen, R.P.; Turner, K.B.; Walper, S.A.; Vranish, J.; Kjems, J.; Ancona, M.G.; Medintz, I.L. Enhanced catalysis from multienzyme cascades assembled on a DNA origami triangle. ACS Nano 2019, 13, 13677-13689. [CrossRef]

191. Zhang, L.; Shi, J.F.; Jiang, Z.Y.; Jiang, Y.J.; Qiao, S.Z.; Li, J.A.; Wang, R.; Meng, R.; Zhu, Y.; Zheng, Y. Bioinspired preparation of polydopamine microcapsule for multienzyme system construction. Green Chem. 2011, 13, 300-306. [CrossRef]

192. Begum, G.; Goodwin, W.B.; deGlee, B.M.; Sandhage, K.H.; Kröger, N. Compartmentalisation of enzymes for cascade reactions through biomimetic layer-by-layer mineralization. J. Mat. Chem. B 2015, 3, 5232-5240. [CrossRef]

193. Bilal, M.; Hussain, N.; Américo-Pinheiro, J.H.P.; Almulaiky, Y.Q.; Iqbal, H.M. Multi-enzyme co-immobilized nano-assemblies: Bringing enzymes together for expanding bio-catalysis scope to meet biotechnological challenges. Int. J. Biol. Macromol. 2021, 186, 735-749. [CrossRef] [PubMed]

194. Omidvar, M.; Zdarta, J.; Sigurdardóttir, S.B.; Pinelo, M. Mimicking natural strategies to create multi-environment enzymatic reactors: From natural cell compartments to artificial polyelectrolyte reactors. Biotechnol. Adv. 2022, 54, 107798. [CrossRef] [PubMed]

195. Peng, F.; Chen, Q.-S.; Zong, M.-H.; Lou, W.-Y. Sequential co-immobilization of multienzyme nanodevices based on SpyCatcher and SpyTag for robust biocatalysis. Mol. Catal. 2021, 510, 111673. [CrossRef]

196. Ren, S.; Li, C.; Jiao, X.; Jia, S.; Jiang, Y.; Bilal, M.; Cui, J. Recent progress in multienzymes co-immobilization and multienzyme system applications. Chem. Eng. J. 2019, 373, 1254-1278. [CrossRef]

197. Zhang, H.; Bai, Y.; Zhu, N.; Xu, J. Microfluidic reactor with immobilized enzyme-from construction to applications: A review. Chin. J. Chem. Eng. 2021, 30, 136-145. [CrossRef]

198. Jia, F.; Narasimhan, B.; Mallapragada, S. Materials-based strategies for multi-enzyme immobilization and co-localization: A review. Biotechnol. Bioeng. 2014, 111, 209-222. [CrossRef] [PubMed]

199. Remonatto, D.; Ferrari, B.R.; Bassan, J.C.; Mussagy, C.U.; de Carvalho Santos-Ebinuma, V.; Veloso de Paula, A. Utilization of Clay Materials as Support for Aspergillus japonicus Lipase: An Eco-Friendly Approach. Catalysts 2021, 11, 1173. [CrossRef]

200. Lyubyakina, P.; Tambasova, D.; Antonov, D.; Kovaleva, E. Complex enzymatic preparations immobilized on aluminum oxide in chitosan breakdown. AIP Conf. Proc. 2020, 2280, 050031. [CrossRef]

201. Nishida, H.; Kajisa, T.; Miyazawa, Y.; Tabuse, Y.; Yoda, T.; Takeyama, H.; Kambara, H.; Sakata, T. Self-oriented immobilization of DNA polymerase tagged by titanium-binding peptide motif. Langmuir 2015, 31, 732-740. [CrossRef] [PubMed]

202. Masuda, Y.; Kugimiya, S.-I.; Kato, K. Improvement of thermal-stability of enzyme immobilized onto mesoporous zirconia. J. Asian Ceram. Soc. 2014, 2, 11-19. [CrossRef]

203. Bôa Morte, E.F.; Marum, D.S.; Saitovitch, E.B.; Alzamora, M.; Monteiro, S.N.; Sanchez Rodriguez, R.J. Modified magnetite nanoparticle as biocatalytic support for magnetically stabilized fluidized bed reactors. J. Mater. Res. Technol. 2021, 14, 1112-1125. [CrossRef]

204. Moisa, M.E.; Spelmezan, C.G.; Paul, C.; Bartha-Vari, J.H.; Bencze, L.C.; Irimie, F.D.; Paizs, C.; Peter, F.; Tosa, M.I. Tailored sol-gel immobilized lipase preparates for the enzymatic kinetic resolution of heteroaromatic alcohols in batch and continuous flow systems. RSC Adv. 2017, 7, 52977-52987. [CrossRef] 
205. Anastasescu, C.; Anastasescu, M.; Balint, I.; Zaharescu, M. $\mathrm{SiO}_{2}$ Based Materials for Immobilization of Enzymes (2019). In Nanomaterials_Toxicity, Human Health and Environment; Clichici, S., Filip, A., Nascimento, G.M., Eds.; IntechOpen: London, UK, 2019; pp. 1-21. [CrossRef]

206. Hartmann, M.; Kostrov, X. Immobilization of enzymes on porous silicas-Benefits and challenges. Chem. Soc. Rev. 2013, 42, 6277-6289. [CrossRef] [PubMed]

207. Pazarlioglu, N.K.; Sariisçik, M.; Telefoncu, A. Treating denim fabrics with immobilized commercial cellulases. Process Biochem. 2005, 40, 767-771. [CrossRef]

208. Sattar, H.; Aman, A.; Qader, S. Agar-agar immobilization: An alternative approach for the entrapment of protease to improve the catalytic efficiency, thermal stability and recycling efficiency. Int. J. Biol. Macromol. 2018, 111, 917-922. [CrossRef] [PubMed]

209. Zucca, P.; Fernandez-Lafuente, R.; Sanjust, E. Agarose and Its Derivatives as Supports for Enzyme Immobilization. Molecules 2016, 21, 1577. [CrossRef]

210. Kurtinaĭtene, B.S.; Kulis, I. Stabilization of native and immobilized urease. Priklad. Biokhim. Mikrobiol. 1987, 23, $299-302$.

211. Yoon, J.; Lee, S.H.; Tieves, F.; Rauch, M.; Hollmann, F.; Park, C.B. Light-harvesting dye-alginate hydrogel for solar-driven, sustainable biocatalysis of asymmetric hydrogenation. ACS Sustain. Chem. Eng. 2019, 7, 5632-5637. [CrossRef]

212. Elnashar, M.M.; Awad, G.E.; Hassan, M.E.; Eldin, M.S.M.; Haroun, B.M.; El-Diwany, A.L. Optimal Immobilization of $\beta$ Galactosidase onto k-Carrageenan Gel Beads Using Response Surface Methodology and Its Applications. Sci. World J. 2014, 2014, 571682. [CrossRef] [PubMed]

213. Verma, M.L.; Kumar, S.; Das, A.; Randhawa, J.S.; Chamundeeswari, M. Enzyme Immobilization on Chitin and Chitosan-Based Supports for Biotechnological Applications. In Sustainable Agriculture Reviews 35; Crini, G., Lichtfouse, E., Eds.; Springer: Cah, Switzerland, 2019; pp. 147-173. [CrossRef]

214. He, S.; Song, D.; Chen, M.; Cheng, H. Immobilization of Lipases on Magnetic Collagen Fibers and Its Applications for Short-Chain Ester Synthesis. Catalysts 2017, 7, 178. [CrossRef]

215. Labus, K.; Wolanin, K.; Radosiński, Ł. Comparative Study on Enzyme Immobilization Using Natural Hydrogel Matrices—Experimental Studies Supported by Molecular Models Analysis. Catalysts 2020, 10, 489. [CrossRef]

216. Jawaheer, S.; White, S.F.; Rughooputh, S.D.D.V.; Cullen, D.C. Enzyme stabilization using pectin as a novel entrapment matrix in biosensors. Anal. Lett. 2002, 35, 2077-2091. [CrossRef]

217. Lee, J.-Y.; Jeon, S.J. Characterization and immobilization on nickel-chelated Sepharose of a glutamate decarboxylase A from Lactobacillus brevis BH2 and its application for production of GABA. Biosci. Biotechnol. Biochem. 2014, 78, 1656-1661. [CrossRef] [PubMed]

218. Bedzo, O.; Trollope, K.; Gottumukkala, L.D.; Coetzee, G.; Görgens, J.F. Amberlite IRA 900 versus calcium alginate in immobilization of a novel, engineered $\beta$-fructofuranosidase for short-chain fructooligosaccharide synthesis from sucrose. Biotechnol. Prog. 2019, 35, e2797. [CrossRef] [PubMed]

219. Rehman, H.U.; Nawaz, M.A.; Pervez, S.; Jamal, M.; Attaullah, M.; Aman, A.; Ul Qader, S.A. Encapsulation of pectinase within polyacrylamide gel: Characterization of its catalytic properties for continuous industrial uses. Heliyon 2020, 6, e04578. [CrossRef] [PubMed]

220. Dencheva, N.; Braz, J.; Scheibel, D.; Malfois, M.; Denchev, Z.; Gitsov, I. Polymer-Assisted Biocatalysis: Polyamide 4 Microparticles as Promising Carriers of Enzymatic Function. Catalysts 2020, 10, 767. [CrossRef]

221. Ghosh, S.; Chaganti, S.R.; Prakasham, R.S. Polyaniline nanofiber as a novel immobilization matrix for the anti-leukemia enzyme L-asparaginase. J. Mol. Catal. B Enzym. 2012, 74, 132-137. [CrossRef]

222. Kumar, N.; Upadhyay, L.S.B. Enzyme Immobilization over Polystyrene Surface Using Cysteine Functionalized Copper Nanoparticle as a Linker Molecule. Appl. Biochem. Biotechnol. 2020, 191, 1247-1257. [CrossRef] [PubMed]

223. Cui, C.; Li, L.; Li, M. Improvement of lipase activity by synergistic immobilization on polyurethane and its application for large-scale synthesizing vitamin A palmitate. Prep. Biochem. Biotechnol. 2019, 49, 485-492. [CrossRef]

224. Alonso-González, M.; Corral-González, A.; Felix, M.; Romero, A.; Martin-Alfonso, J.E. Developing active poly(vinyl alcohol)based membranes with encapsulated antimicrobial enzymes via electrospinning for food packaging. Int. J. Biol. Macromol. 2020 162, 913-921. [CrossRef] [PubMed]

225. Li, D.; Fang, Z.; Duan, H.; Liang, L. Polydopamine-mediated synthesis of core-shell gold@calcium phosphate nanoparticles for enzyme immobilization. Biomater. Sci. 2019, 7, 2841-2849. [CrossRef] [PubMed]

226. Shao, P.; He, Z.; Hu, Y.; Shen, Y.; Zhang, S.; Yu, Y. Zeolitic imidazolate frameworks with different organic ligands as carriers for Carbonic anhydrase immobilization to promote the absorption of $\mathrm{CO}_{2}$ into tertiary amine solution. Chem. Eng. J. 2022, 435, 134957. [CrossRef]

227. Du, K.; Sun, J.; Zhou, X.; Feng, W.; Jiang, X.; Ji, P. A two-enzyme immobilization approach using carbon nanotubes/silica as support. Biotechnol. Prog. 2015, 31, 42-47. [CrossRef] [PubMed]

228. Laranjo, M.T.; Morawski, F.M.; Dias, S.L.P.; Benvenutti, E.V.; Arenas, L.T.; Costa, T.M.H. Silica/Titania Graphite Composite Modified with Chitosan and Tyrosinase Employed as a Sensitive Biosensor for Phenolic Compounds. J. Braz. Chem. Soc. 2019, 30, 2660-2672. [CrossRef]

229. Convery, N.; Gadegaard, N. 30 Years of Microfluidics. Micro Nano Eng. 2019, 2, 76-91. [CrossRef]

230. Benítez-Mateos, A.I.; Contente, M.L.; Roura Padrosa, D.; Paradisi, F. Flow biocatalysis: Design, development and applications. React. Chem. Eng. 2021, 6, 599-611. [CrossRef] 
231. Ward, K.; Fan, Z.H. Mixing in microfluidic devices and enhancement methods. J. Micromech. Microeng. 2015, 25, 094001. [CrossRef]

232. Elvira, K.; Solvas, X.; Wootton, R.; deMello, A.J. The past, present and potential for microfluidic reactor technology in chemical synthesis. Nat. Chem. 2013, 5, 905-915. [CrossRef]

233. Šalić, A.; Zelić, B. Synergy of Microtechnology and Biotechnology: Microreactors as an Effective Tool for Biotransformation Processes. Food Technol. Biotechnol. 2018, 56, 464-479. [CrossRef] [PubMed]

234. Prado, R.C.; Borges, E.R. Microbioreactors as Engineering Tools for Bioprocess Development. Braz. J. Chem. Eng. 2018, 35, 1163-1182. [CrossRef]

235. Calleri, E.; Temporini, C.; Colombo, R.; Tengattini, S.; Rinaldi, F.; Brusotti, G.; Furlanetto, S.; Massolini, G. Analytical settings for in-flow biocatalytic reaction monitoring, TrAC. Trends Anal. Chem. 2021, 143, 116348. [CrossRef]

236. Gkantzou, E.; Patila, M.; Stamatis, H. Magnetic Microreactors with Immobilized Enzymes-From Assemblage to Contemporary Applications. Catalysts 2018, 8, 282. [CrossRef]

237. Žnidaršič-Plazl, P. The Promises and the Challenges of Biotransformations in Microflow. Biotechnol. J. 2019, 14, 1800580. [CrossRef] [PubMed]

238. De Santis, P.; Meyer, L.-E.; Kara, S. The rise of continuous flow biocatalysis-Fundamentals, very recent developments and future perspectives. React. Chem. Eng. 2020, 5, 2155-2184. [CrossRef]

239. Zhu, Y.; Chen, Q.; Shao, L.; Jia, Y.; Zhang, X. Microfluidic immobilized enzyme reactors for continuous biocatalysis. React. Chem. Eng. 2020, 5, 9-32. [CrossRef]

240. Santi, M.; Sancineto, L.; Nascimento, V.; Braun Azeredo, J.; Orozco, E.V.M.; Andrade, L.H.; Gröger, H.; Santi, C. Flow Biocatalysis: A Challenging Alternative for the Synthesis of APIs and Natural Compounds. Int. J. Mol. Sci. 2021, 22, 990. [CrossRef] [PubMed]

241. Amin, F.; Haq, N.B.; Muhammad, B. Recent advances in the production strategies of microbial pectinases-A review. Biol. Macromol. 2019, 122, 1017-1026. [CrossRef]

242. Huang, D.; Yuyang, S.; Yanlin, L.; Yi, Q. A new strain of Aspergillus tubingensis for high-activity pectinase production. Braz. J. Microbiol. 2019, 50, 53-65. [CrossRef]

243. Satapathy, S.; Rout, J.R.; Kerry, R.G.; Thatoi, H.; Sahoo, S.L. Biochemical Prospects of Various Microbial Pectinase and Pectin: An Approachable Concept in Pharmaceutical Bioprocessing. Front. Nutr. 2020, 7, 117. [CrossRef]

244. Khan, M.; Ekambaram, N.; Umesh-Kumar, S. Potential Application of Pectinase in Developing Functional Foods. Annu. Rev. Food Sci. Technol. 2013, 4, 21-34. [CrossRef] [PubMed]

245. Alimardani-Theuil, P.; Gainvors-Claisse, A.; Duchiron, F. Yeasts: An attractive source of pectinases-From gene expression to potential applications: A review. Process. Biochem. 2011, 46, 1525-1537. [CrossRef]

246. de Oliveira, R.L.; Osmar, S.S.; Attilio, C.; Tatiana, S.P. Thermodynamic and kinetic studies on pectinase extracted from Aspergillus aculeatus: Free and immobilized enzyme entrapped in alginate beads. Int. J. Biol. Macromol. 2018, 115, 1088-1093. [CrossRef] [PubMed]

247. Takc, H.A.; Mercimek, U.T. Extracellular pectinase production and purification from a newly isolated Bacillus subtilis strain. Int. J. Food Prop. 2016, 19, 2443-2450.

248. Voragen, A.G.J.; Gerd-Jan, C.; Rene, P.V.; Henk, A.S.P. Pectin a versatile polysaccharide present in plant cell walls. Struct. Chem. 2009, 20, 263-275. [CrossRef]

249. Favela, T.; Volke-Sepúlveda, T.; Viniegra-González, G. Production of Hydrolytic Depolymerising Pectinases. Food Technol. Biotechnol. 2006, 44, 221-227.

250. Gonçalves, D.B.; Teixeira, J.A.; Bazzolli, D.M.S.; Queiroz, M.V.D.; Araújo, E.F. Use of response surface methodology to optimize production of pectinases by recombinant Penicillium griseoroseum T20. Biocat. Agric. Biotechnol. 2012, 1, 140-146. [CrossRef]

251. Govindaraji, P.K.; Vuppu, S. Characterization of pectin and optimization of pectinase enzyme from novel Streptomyces fumigatiscleroticus VIT-SP4 for drug delivery and concrete crack-healing applications: An eco-friendly approach. Saudi J. Biol. Sci. 2020, 20, 3529-3540. [CrossRef]

252. Ortiz, G.E.; María, C.; Ponce, M.; Diego, G.N.; Gabriela, C.; Celina, S.; María, C.L.; Guillermo, P.G.; Martín, B.; Edgardo, O.A. Pectinase production by Aspergillus giganteus in solid state fermentation: Optimization, scale-up, biochemical characterization and its application in olive oil extraction. J. Ind. Microbiol. Technol. 2017, 44, 197-211. [CrossRef] [PubMed]

253. Angelim, A.L.; Samantha, P.C.; Cibelle, B.F.L.; Freitas, A.; Vânia, M.M. An innovative bioremediation strategy using a bacterial consortium entrapped in chitosan beads. J. Environ. Manag. 2013, 127, 10-17. [CrossRef] [PubMed]

254. Di Carlo, D. Inertial Microfluidics. Lab Chip 2009, 9, 3038-3046. [CrossRef]

255. Dai, X.Y.; Kong, L.M.; Wang, X.L.; Zhu, Q.; Chen, K.; Zhou, T. Preparation, characterization and catalytic behavior of pectinase covalently immobilized onto sodium alginate/graphene oxide composite beads. Food Chem. 2018, 253, 185-193. [CrossRef]

256. Dal Magro, L.; Silveira, V.C.C.; de Menezes, E.W.; Benvenutti, E.V.; Nicolodi, S.; Hertz, P.F.; Klein, M.P.; Rodrigues, R.C. Magnetic biocatalysts of pectinase and cellulase: Synthesis and characterization of two preparations for application in grape juice clarification. Int. J. Biol. Macromol. 2018, 115, 35-44. [CrossRef] [PubMed]

257. Djordjevic, V.; Willaert, R.; Gibson, B.; Nedovic, V. Immobilized yeast cells and secondary metabolites. In Fungal Metabolites; Reference Series in Phytochemistry; Mérillon, J.M., Ramawat, K., Eds.; Springer: Cham, Switzerland, 2016; pp. 599-638.

258. Sojitra, U.V.; Nadar, S.S.; Rathod, V.K. A magnetic tri-enzyme nanobiocatalyst for fruit juice clarification. Food Chem. 2016, 213, 296-305. [CrossRef] [PubMed] 
259. Muley, A.B.; Thorat, A.S.; Singhal, R.S.; Harinath Babu, K. A tri-enzyme coimmobilized magnetic complex: Process details, kinetics, thermodynamics and applications. Int. J. Biol. Macromol. 2018, 118, 1781-1795. [CrossRef]

260. Nadar, S.S.; Rathod, V.K. A co-immobilization of pectinase and cellulase onto magnetic nanoparticles for antioxidant extraction from waste fruit peels. Biocatal. Agric. Biotechnol. 2019, 17, 470-479. [CrossRef]

261. Voberkov, S.; Solcany, V.; Vrsansk, M.; Adam, V. Immobilization of ligninolytic enzymes from white rot fungi in cross-linked aggregates. Chemosphere 2020, 18, 694-707. [CrossRef]

262. Trappey, A.F.; Johnson, C.E.; Wilson, P.W. Use of a Commercial Pectolytic Enzyme to Extract Juice from Frozen Mayhaw (Crataegus opaca Hook.) Fruit. Int. J. Fruit Sci. 2007, 7, 77-86. [CrossRef]

263. Cho, E.; Jung, S.; Kim, H.; Lee, H.Y.; Nam, K.; Lee, H.; Bae, H. Co-immobilization of three cellulases on Au-doped magnetic silica nanoparticles for the degradation of cellulose. Chem. Commun. 2012, 48, 886-888. [CrossRef] [PubMed]

264. Nadar, S.S.; Rathod, V.K. Magnetic nanobiocatalyst for extraction of bioactive ingredients: A novel approach. Trends Food Sci. Technol. 2020, 103, 225-238. [CrossRef]

265. Demir, N.; Jale, A.; Kemal, S.; Mehmet, M. The use of commercial pectinase in fruit juice industry, Part 3: Immobilized pectinase for mash treatment. J. Food Eng. 2001, 47, 275-280. [CrossRef]

266. Spagna, G.; Romagnoli, D.; Martino, A.; Bianchi, G.; Pier, B.; Pifferi, G. A simple method for purifying glycosidases: $\alpha$-Lrhamnopyranosidase from Aspergillus niger to increase the aroma of Moscato wine Giovanni Spagna. Enzym. Microb. Technol. 2000, 27, 522-530. [CrossRef]

267. Puri, M. Updates on naringinase: Structural and biotechnological aspects. Appl. Microbiol. Biotechnol. 2012, 93, 49-60. [CrossRef] [PubMed]

268. Ribeiro, M.H.L. Naringinases: Occurrence, characteristics, and applications. Appl. Microbiol. Biotechnol. 2011, 90, 1883-1895. [CrossRef]

269. Ferreira, L.; Afonso, C.; Vila-Real, H.; Alfaia, A.; Ribeiro, M.H.L. Evaluation of the Effect of High Pressure on Naringin Hydrolysis in Grapefruit Juice with Naringinase Immobilised in Calcium Alginate Beads. Food Technol. Biotechnol. 2008, 46, 146-150.

270. Ribeiro, M.H.L.; Rabaça, M. Cross-linked enzyme aggregates of naringinase: Novel biocatalysts for naringin hydrolysis. Enzyme Res. 2011, 8, 851272. [CrossRef]

271. Martins, S.L.; Albuquerque, B.F.; Nunes, M.A.P.; Ribeiro, M.H.L. Exploring magnetic and imprinted cross-linked enzyme aggregates of rhamnopyranosidase in microbioreactors. Bioresour. Technol. 2017, 247, 704-712. [CrossRef]

272. Nunes, M.A.P.; Fernandes, P.C.B.; Ribeiro, M.H.L. High affinity water-soluble system for efficient naringinase immobilization in polyvinyl alcohol-dimethyl sulfoxide lens-shaped particles. J. Mol. Recognit. 2012, 25, 580-594. [CrossRef]

273. Onbas, R.; Ozlem, Y.C. Synthesis of alginate-silica hybrid hydrogel for biocatalytic conversion by $\beta$-glucosidase in microreactor. Eng. Life Sci. 2018, 19, 37-46. [CrossRef]

274. Berbegal, C.; Spano, G.; Tristezza, M.; Griego, F.; Capozzi, V. Microbial resources and innovation in the wine production sector. $S$. Afr. J. Enol. Vitic. 2017, 38, 156-166. [CrossRef]

275. Park, M.; Sun, Q.; Liu, F.; DeLisa, M.P.; Chen, W. Positional assembly of enzymes on bacterial outer membrane vesicles for cascade reactions. PLoS ONE 2014, 9, e97103. [CrossRef] 